\title{
Toward Sustainable Cementitious Radioactive Waste Forms: Immobilization of Problematic Operational Wastes
}

\author{
Rehab O. Abdel Rahman ${ }^{1, *(D)}$ and Michael I. Ojovan ${ }^{2,3}$ (D) \\ 1 Hot Laboratory Center, Atomic Energy Authority of Egypt, Cairo 13759, Egypt \\ 2 Department of Materials, South Kensington Campus, Imperial College London, Exhibition Road, \\ London SW7 2AZ, UK; m.ojovan@imperial.ac.uk \\ 3 Institute of Geology of Ore Deposits, Petrography, Mineralogy and Geochemistry of Russian Academy of \\ Sciences (IGEM RAS), 119017 Moscow, Russia \\ * Correspondence: alaarehab@yahoo.com; Tel.: +20-10-6140-4462
}

Citation: Abdel Rahman, R.O.;

Ojovan, M.I. Toward Sustainable Cementitious Radioactive Waste Forms: Immobilization of Problematic Operational Wastes. Sustainability 2021, 13, 11992. https://doi.org/10.3390/ su132111992

Academic Editor: Silvia Fiore

Received: 27 September 2021

Accepted: 26 October 2021

Published: 29 October 2021

Publisher's Note: MDPI stays neutral with regard to jurisdictional claims in published maps and institutional affiliations.

Copyright: (c) 2021 by the authors. Licensee MDPI, Basel, Switzerland. This article is an open access article distributed under the terms and conditions of the Creative Commons Attribution (CC BY) license (https:// creativecommons.org/licenses/by/ $4.0 /)$.

\begin{abstract}
Developing effective radioactive waste management practices is essential for ensuring the sustainability of the nuclear industry. The immobilization of radioactive wastes is one of the main activities conducted during the management of these wastes; it aims to produce a durable waste form that has sustainable performance over long periods of time. In this work, the challenges that face the design of durable cementitious waste forms are addressed for problematic operational wastes. In this respect, the problematic characteristics of evaporator concentrates, spent ion exchangers, and organic liquid wastes are overviewed, and the factors that affect the durability of their cementitious waste forms are identified. A summary of potential conventional and innovative cementitious matrices is presented by reviewing the cementation practices in national programs and recent research devoted to developing durable matrices. Finally, a guide to optimize the mix design of these waste forms was proposed that includes the selection of the testing procedure, factors that affect the waste form performance, and the optimization technique. This guide was presented with special focus on leaching tests, which are a means to test the stabilization performance of nuclear waste forms.
\end{abstract}

Keywords: radioactive waste; evaporator concentrates; spent ion exchangers; organic liquid wastes; conventional cement; innovative cement; mix design optimization; leaching tests

\section{Introduction}

The nuclear industry is supporting the sustainability of human life, as the continuous development of nuclear energy aims to secure sustainable, clean, and affordable energy and clean water. Moreover, the advance in isotopic techniques aims to improve the agricultural sector toward zero hunger, support the medical sector for good health and well-being, enhance industrial innovation and infrastructure, and support efforts to protect life below water and on land [1]. In general, the operation of the energy production sector results in large extraction, processing, storing, and transportation of raw materials, as well as processed fuel utilization and management of the generated wastes and emissions. The sustainable development indicators for this sector comprise different economic, social, institutional, and environmental dimensions. In particular, the environmental indicators focus on resources, wastes and emissions (e.g., amounts and characteristics of the used fuel and generated wastes and emissions), and land impacts [1-4]. Subsequently, the amount of the generated solid wastes due to the production of unit energy $(\mathrm{g} / \mathrm{kW} \cdot \mathrm{h})$ is used as an environmental indicator on the sustainability of certain energy sectors [1,3,4]. The International Atomic Energy Agency (IAEA) compared this indicator for different energy production industries for both upstream and operational processes, and the results are summarized in Figure 1 [4]. It is clear from this figure that the upstream operations of renewable energy sources generate very small amounts of solid wastes per unit energy $(300-0.98 \mathrm{~g} / \mathrm{kW} \cdot \mathrm{h})$ compared to that of the coal industry $(3000 \mathrm{~g} / \mathrm{kW} \cdot \mathrm{h})$ (Figure 1a), where 
most of the generated solid wastes from the nuclear energy sector are non-radioactive and non-hazardous wastes $(0.97 \mathrm{~g} / \mathrm{kW} \cdot \mathrm{h})$. The same results are shown for the operational processes of these industries, where lignite coal generates the highest amount of solid waste per unit energy. The nuclear industry generates total operational wastes comparable to that generated from natural gas. Only $5.1 \%$ of these wastes have a radiological hazard: where low and intermediate level radioactive wastes (LILW)represent $4.52 \%$, and the rest are high level wastes (HLW), spent fuels, and hazardous wastes (Figure 1b).
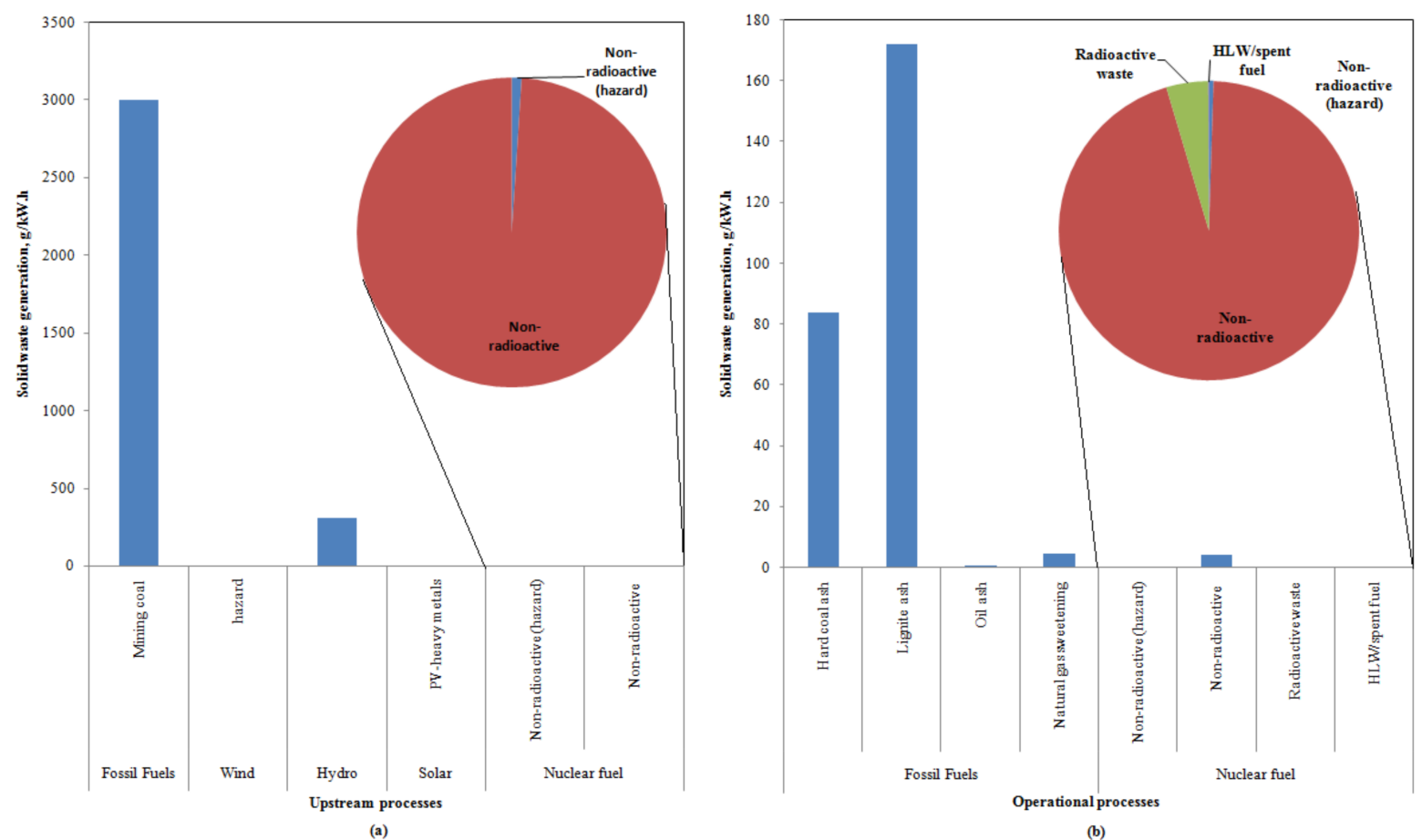

Figure 1. Amount of solid wastes generation per unit energy generation in different energy industries: (a) upstream processes; (b) operational processes [4].

Although the nuclear energy industry generates small amounts of operational wastes, the analysis of its sustainability considers emissions and radioactive waste generation and management as key sustainability factors $[4,5]$. This is attributed to the radiological hazards of these wastes and emissions that can last for long times, e.g., several decades for short-lived LILW, according to the 10 half-lives rule of thumb. Subsequently, operational and research efforts are directed at minimizing the waste generation and enhancing the waste management practices, to eliminate the long-term impacts of these wastes on human health and the environment. The management of radioactive wastes typically consists of pre-disposal and disposal activities; the first is sub-categorized into pre-treatment, treatment, and conditioning activities, as illustrated in Figure 2 [6]. Pre-treatment and treatment activities aim to reduce the volume of generated wastes to enhance the safety and/or reduce the costs of the subsequent management activities [7]. The treated wastes are directed to immobilization then packaging, to fabricate a waste package that is able to withstand handling and transport conditions and is durable under storage and disposal conditions (Figure 2). The immobilized waste form should be designed and fabricated in a way that ensures its sustainable performance for centuries in the case of LILW and for millennia in the case of HLW. It should be noted that during the early era of the nuclear industry, LILW were packaged and disposed of without immobilization. Based on the lessons learned from early disposal practices, the waste immobilization activity was introduced. Since then, a large number of research groups focused their work on this topic: among these groups are the Atomic Energy of Canada Limited's (AECL) Chalk River Laboratories, Comisión Nacional de Energia Atómica (CNEA) in Argentina, the Scientific 
and Industrial Association (RADON) in the Russian Federation, Empresa Nacional de Residuos Radioactivos S.A. (ENRESA) in Spain, the Brookhaven National Laboratory in USA, etc. Detailed information on early immobilization and disposal practices can be found elsewhere [8-18]. An analysis of the bibliometric data in the Scopus database was conducted in order to gain insights into the scientific research interests in the field of radioactive waste management in general and, in particular, on the topics related to radioactive waste forms. The analysis conducted in July 2021 showed 57,887 documents in the database using the keywords "Radioactive AND wastes". The search was refined using more keywords with the operator "AND", and the results are summarized in Figure 3a-c. It is noted that research related to radioactive waste forms represent nearly $10 \%$ of the work that addressed radioactive waste (Figure 3a). The factors that affect its performances represent about $8.72 \%$ of the research conducted in this field (Figure $3 b$ ).

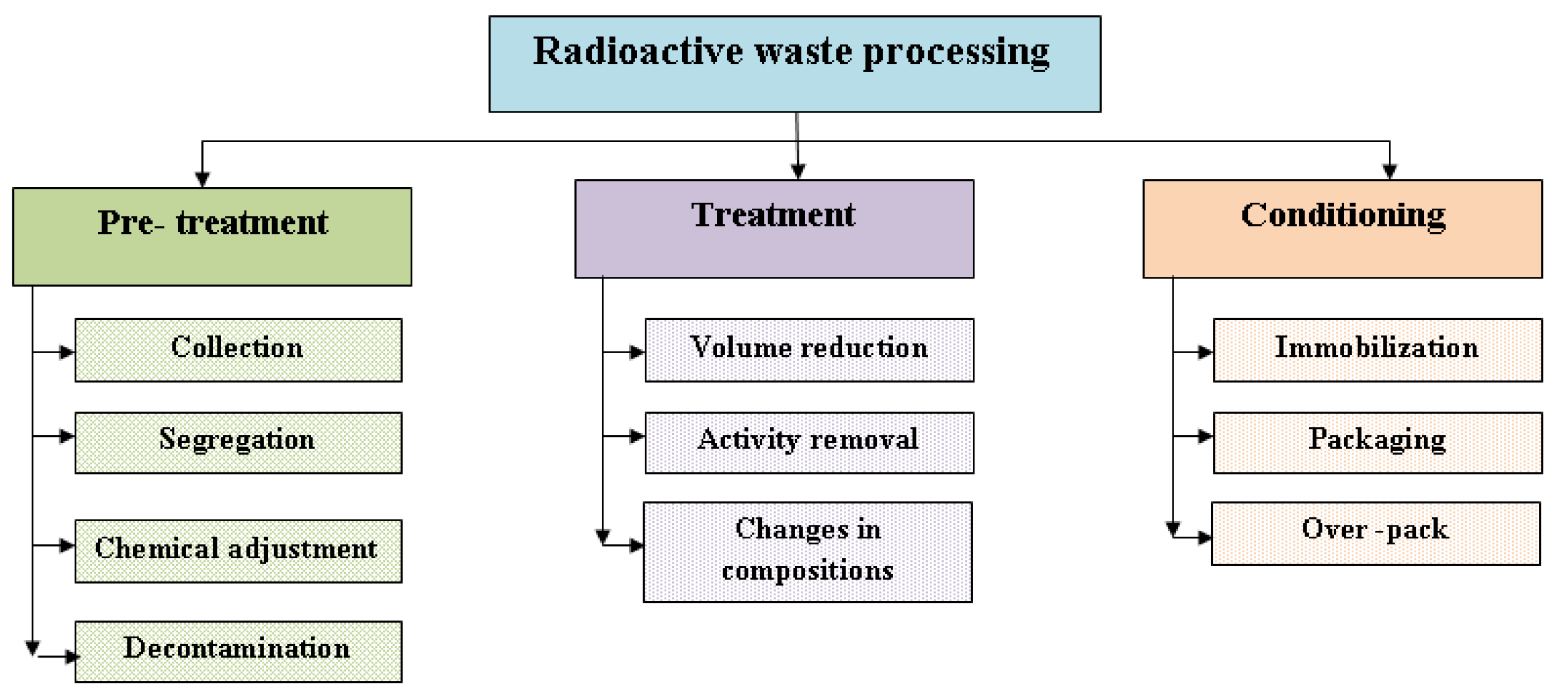

Figure 2. Pre-disposal activities in a radioactive waste management system (copyrighted R.O. Abdel Rahman, et al., Improving the Performance of Engineering Barriers in Radioactive Waste Disposal Facilities: Role of Nano-Materials. In: Kharissova O., Martínez L., Kharisov B. (eds) Handbook of Nanomaterials and Nanocomposites for Energy and Environmental Applications. Springer, Cham, 1183-1200 [6]).

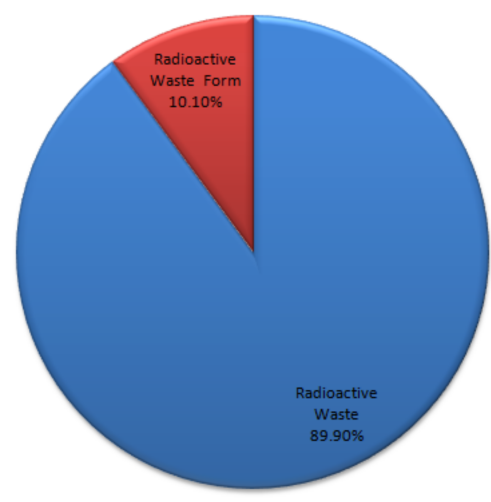

(a)

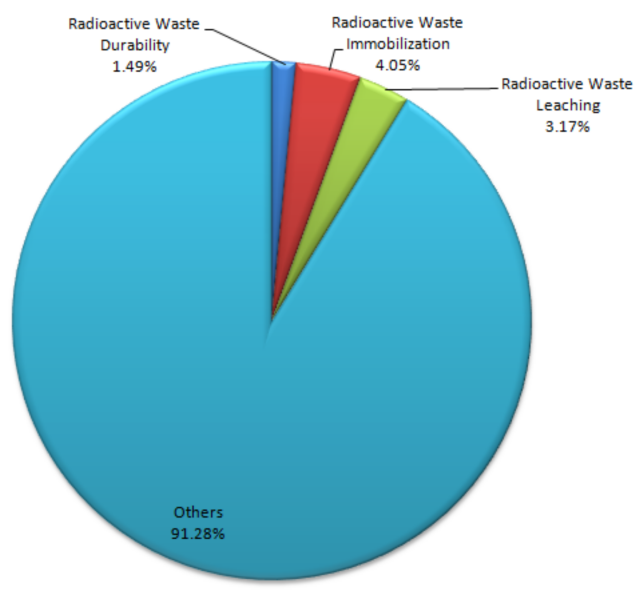

(b)

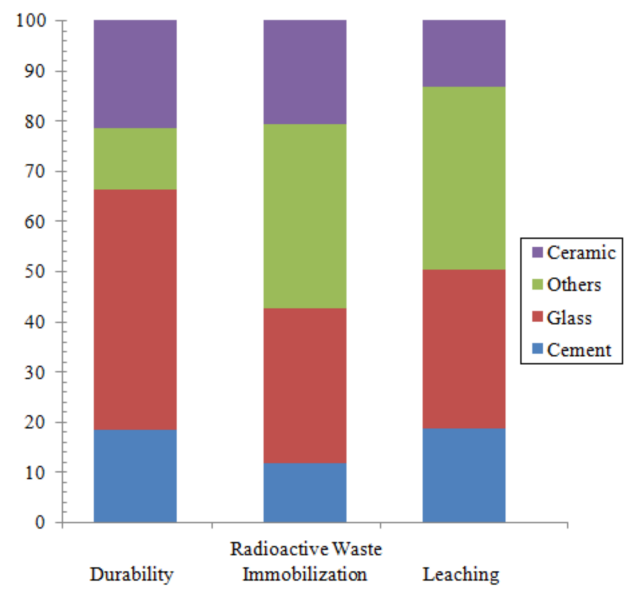

(c)

Figure 3. Bibliometric data in the field of radioactive wastes, the contribution of research related to (a) waste forms, (b) radioactive waste immobilization, durability, and leaching. (c) relative contributions of immobilization media in researches related to radioactive waste immobilization, durability and leaching. 
Cements, ceramics, glasses, and polymers are widely used as immobilizing matrices for radioactive wastes; they contain and confine several types of radio-contaminants. The sub-categorization of the refined bibliometric data for research directed at investigating radioactive waste immobilization, durability, and leaching is illustrated in Figure 3c. These data show that research focused on solving challenges in the application of cementitious, glass, and ceramic wastes. Figure 4 shows a summary of the annual distribution of the research conducted in the field of radioactive waste for glass and cement materials. It is clear that the research related to the latter increased over the last 10 years compared to that for the first (Figure 4a). The annual distribution of the published glass research in the database is slightly higher than that of the cement research (Figure $4 b$ ).

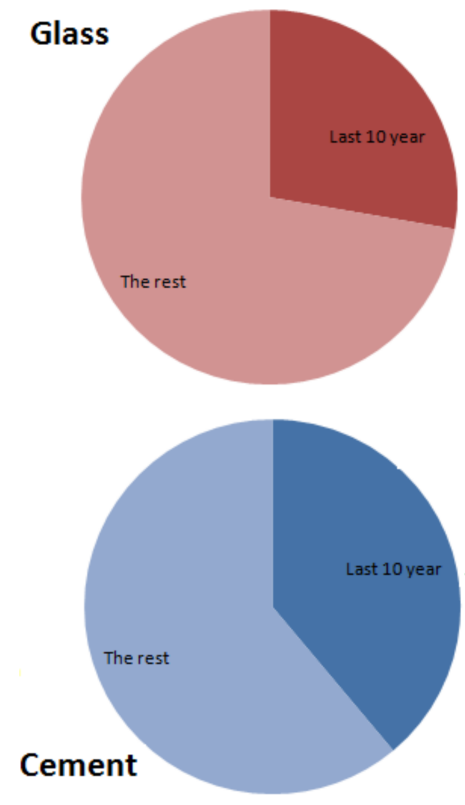

(a)

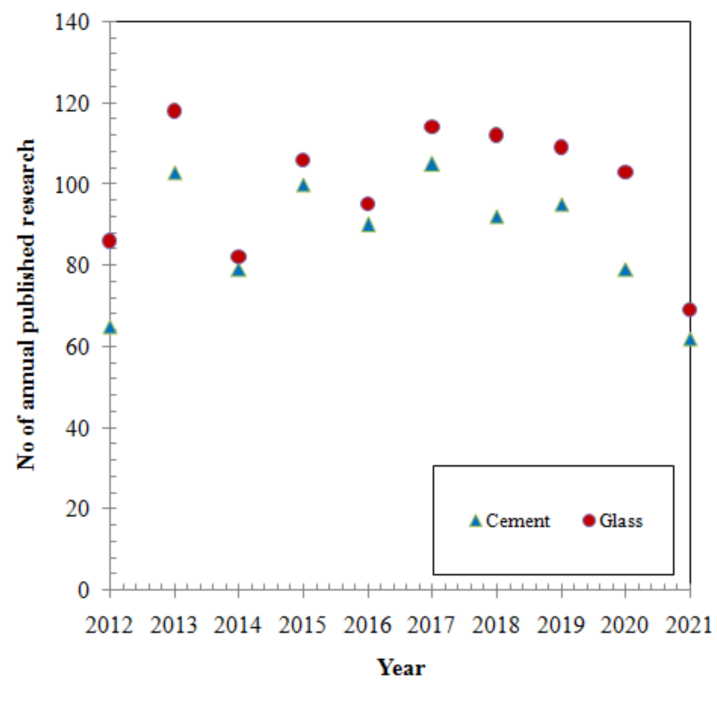

(b)

Figure 4. Summary of the progress in the annual published research in the radioactive waste field: (a) contribution of the published research in the last decade; (b) number of annual published research in the last decade.

The immobilization of radioactive wastes in cementitious matrices is achieved via two simultaneous processes, i.e., solidification and stabilization. The first aims to enhance the mechanical performance of the produced waste form, and the second aims to reduce the mobility of radio-contaminants [19]. In this paper, the focus is on challenges that face the design of sustainable cementitious waste forms for problematic operational wastes. In general, problematic wastes are wastes that require special considerations during the selection of management options, owing to their specific characteristics [20]. Spent ion exchangers, borate- and sulfate-containing wastes, organic liquid wastes, and decontamination solutions containing detergent, organic, and/or acidic solutions are operational wastes that are considered problematic during the design of the cementitious waste forms [21-23]. If directly immobilized, some components in these streams interfere in the hydration reactions of conventional Ordinary Portland Cements (OPC), leading to undesired micro- and macro-changes in the produced waste forms that affect their solidification and stabilization performances. To counteract these changes, the mix design of the cementitious immobilization matrices is modified to include additives or use of innovative cements. The main aim of this work is to summarize the key problematic characteristics of these waste streams, assess the factors that affect the durability of the produced cementitious waste forms, and identify the approaches used in designing these forms. 


\section{Cementitious Matrices to Immobilize Operational Wastes}

Cementitious matrices are widely applied as immobilization media to host several types of radioactive wastes, and this application is supported by their [23-25]:

- Compatibility with different waste streams.

- Capability to activate different immobilization mechanisms.

- Chemical, thermal, and radiological stabilities.

- Low operational cost, ease of operation, and ambient temperature operation.

- Ability to maintain the high $\mathrm{pH}$ environment in the disposal facility.

These matrices are categorized into conventional and innovative matrices. The first matrix is composed of a conventional hydraulic binder, i.e., Ordinary Portland Cement (OPC) with or without additives, whereas the second includes calcium aluminate cements (CAC), calcium sulfo-aluminate cements (CSAC), magnesium phosphate cements (MPC), and alkali-activated cements (AAC) $[23,26,27]$. The design of cementitious waste forms is a crucial process, aiming toward the achievement of a durable form that possesses reliable long-term performance under storage and disposal conditions. During the design phase, quality requirements on raw materials and the chemical and physical characteristics of the waste stream should be considered [26-29]. In addition, the factors that affect the operation of the cementation process, e.g., the setting time and flow-ability of the paste and the radiological dose on the surface of the waste form, should be taken into account. Finally, the nature of the storage or disposal concept and the required safety functions of the waste forms are key aspects in identifying a proper mix design. In general, the compressive strength, leaching resistance, and permeability are used as performance indicators during the design of the cementitious waste forms to assess solidification, stabilization, and hydraulic performances [30]. The design of the immobilization process includes the following steps:

- Identification of the waste characteristics, e.g., components that influence the hydration reactions.

- Preliminary selection of the immobilization matrices components.

- Optimization of the mix-design, e.g., determination of the waste loading percentage, cement to additive ration, cement to water ratio, etc.

\subsection{Immobilization of Evaporator Concentrates}

Evaporation is a conventional wastewater treatment technology that aims to reduce the volume of the generated aqueous wastes; this technology is reliable and efficient with decontamination factors in the range $10^{4}-10^{6}$. Evaporators are usually used in the combined aqueous waste treatment process in nuclear power plants and in centralized waste management facilities. As a result of the evaporation process, the aqueous waste splits into two streams: the first is of large a volume and very low radioactivity content that could be discharged from the regulatory control, i.e., condensate, and the second is a small volume stream that contains high radioactivity, i.e., concentrates or bottom residues. Concentrates are usually classified as LILW, which are directed to post-treatment then immobilization or just directed to immobilization, based on the selected immobilization matrix type.

\subsubsection{General Characteristics of Concentrates and Their Problematic Nature}

Concentrates are high salt solutions with typical specific activity concentrations in the range $10^{6}-10^{8} \mathrm{~Bq} / \mathrm{L}$ [31]. Major contaminants in the evaporator concentrates are fission products such as ${ }^{137} \mathrm{Cs},{ }^{60} \mathrm{Co},{ }^{54} \mathrm{Mn}$, borates $\left(\mathrm{NaBO}_{2}\right.$ and $\left.\mathrm{Na}_{2} \mathrm{~B}_{4} \mathrm{O}_{7}\right)$, nitrates $\left(\mathrm{NaNO}_{3}\right.$, $\mathrm{KNO}_{3}$ ), hydroxides ( $\mathrm{NaOH}$ and $\left.\mathrm{KOH}\right)$, and some organic compounds, i.e., oxalates [31-33]. In general, alkali and alkaline fission products, e.g., ${ }^{85} \mathrm{Sr},{ }^{137} \mathrm{Cs}$, are characterized by their respective high solubility in the cementitious matrices [34,35]. This behavior affects only the stabilization performance of the waste form. Borates, phosphates, sulfates, nitrates, fluorides, and organic compounds are known for their interference in the hydration reactions, 
leading to them either retarding or accelerating the hydration process [23]. If the content of these components is high enough, they can affect drastically the solidification, stabilization, and hydraulic performances, e.g., the presence of sulfates at considerable amounts reduces the setting time and was reported to cause false rapid setting and increase the expansion and cracking of cement paste [21]. Radioactive borate wastes are produced in pressurized water reactors (PWR). The typical characteristics of the evaporator concentrates, produced from deep and normal evaporators installed in nuclear power plants (NPP) with pressurized reactors of the water-water energetic reactor (WWER) type, are listed in Table 1 [36]. Despite the fact that there are clear variations in the composition of the concentrate in terms of chemical composition and specific radioactivity, borate represents a major component in this stream, which limits the waste loading to a very low wt.\% [37].

Table 1. Typical characteristics of different evaporator concentrates in WWER.

\begin{tabular}{cccc}
\hline \multirow{2}{*}{ Characteristics } & Salt Cake & \multicolumn{2}{c}{ NPPs Jaslovske } \\
\cline { 3 - 4 } & & V-1 NPP & V-2 NPP \\
\hline $\mathrm{pH}$ & - & $11.3-13.3$ & $11.2-13.2$ \\
Density, $\mathrm{kg} / \mathrm{m}^{3}$ & $1500-1800$ & 1414 & - \\
Specific radioactivity, Bq/kg & $<3.7 \times 10^{7}$ & $<1.2 \times 10^{7}$ & $<3.39 \times 10^{5}$ \\
Dry salt content, Kg/L & $1.3-1.5$ & $0.15-0.397$ & $0.15-0.321$ \\
\hline & Chemical composition, g/L & \\
\hline $\mathrm{Na}^{+}$ & $180-220$ & $42-100$ & $25.3-75$ \\
$\mathrm{~K}^{+}$ & $30-55$ & $9.4-21.5$ & $9.1-26$ \\
$\mathrm{H}_{3} \mathrm{BO}_{3}$ & $280-350$ & $73-160$ & $64-117$ \\
$\mathrm{Cl}^{-}$ & $2-5$ & $0.9-1.8$ & - \\
$\mathrm{NO}_{3}^{-}$ & $200-350$ & $5-29.6$ & - \\
$\mathrm{SO}_{4}{ }^{-2}$ & $10-15$ & $14.5-24.8$ & $0.6-5.6$ \\
\hline Organic content & $20-30$ & $14.5-34.8$ &
\end{tabular}

In particular, borates are known for their effects on the solidification process, i.e., strength reduction and the operability of the process, i.e., retarding effects. The effect of borate on the hydration of different cementitious phases had been studied over the past three decades. These studies indicated that $[21,23,27,38-42]$ :

1. During tri-calcium silicate $\left(\mathrm{C}_{3} \mathrm{~S}\right)$ hydration, borate will consume some of the formed portlandite to form amorphous or poor crystalline calcium borate hydrates (CBHs).

2. The clinker grains will be partially or fully covered with an impermeable CBHs layer, which in turn suppresses the hydration reactions.

3. The solubility of the $\mathrm{CBH}$ is affected by the changes in the pore solution $\mathrm{pH}$ and is precipitated as crystallized phases at $\mathrm{pH}>12$ and the hydration is resumed.

A recent study that explored the immobilization of $5.26 \% \mathrm{~B}_{2} \mathrm{O}_{3}$ in OPC indicated that the heat release during the early hydration stage is considerably affected by the presence of $\mathrm{B}_{2} \mathrm{O}_{3}$ [39]. Within the first hour of hydration, $\mathrm{B}_{2} \mathrm{O}_{3}$ dissolution leads to a sensible increase in the released heat ( $0-a$ in Figure $5 a)$. Then, the heat release is suppressed ( $a-d$ in Figure 5a). XRD patterns for OPC and OPC $-\mathrm{B}_{2} \mathrm{O}_{3}$ samples at 28 days showed that the formation of ettringite and portlandite formation are hindered in the borated sample. The presence of unhydrated phases, e.g., $\mathrm{C}_{3} \mathrm{~S}$ and $\mathrm{C}_{2} \mathrm{~S}$, evidences the suppression of the hydration process in that sample and the formation of $\mathrm{CaB}_{2} \mathrm{O}_{4} .4 \mathrm{H}_{2} \mathrm{O}$ refers to a reaction between the formed portlandite at an early time with the borate. These changes were associated with a reduction in the compressive strength from 46.4 to $6.6 \mathrm{MPa}$ at 28 days [39]. Thus, the mix design of specified evaporator concentrates should account for the effect of borate on the hydration of the cementitious matrix. In addition, the durability of the waste from under long-term exposure to environmental conditions and the radiation field should be accounted for during the design $[43,44]$. 


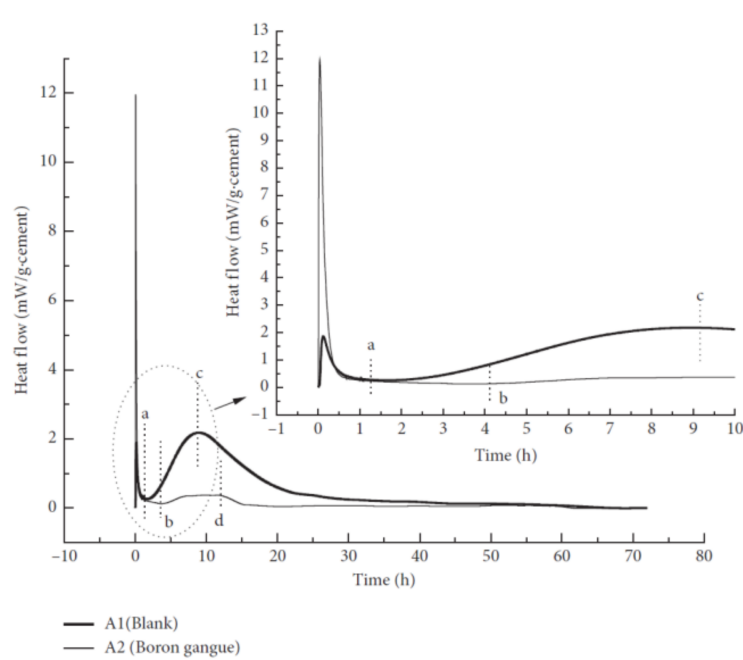

(a)

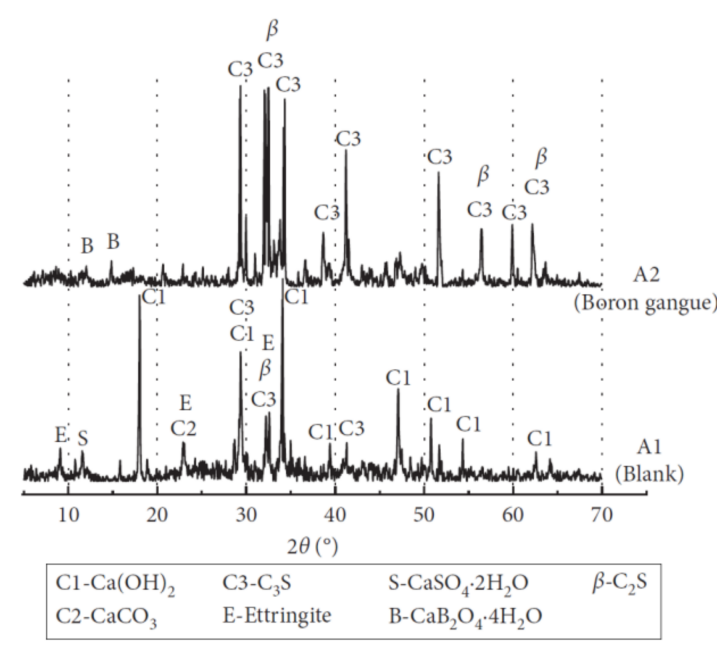

(b)

Figure 5. Effect of $\mathrm{B}_{2} \mathrm{O}_{3}$ on the hydration of ordinary Portland cement 42.5: (a) heat flow; (b) XRD patterns for 28-day hydrated cement (copyrighted Q. Zhao, J. Tu, W. Han, X. Wang, Y. Chen, Hydration Properties of Portland Cement Paste with Boron Gangue, Advances in Materials Science and Engineering (2020) 7194654, 9 pages, https://doi.org/10.1155/2020 /7194654).

\subsubsection{Potential Cementitious Immobilization Matrices for Concentrates}

Both conventional and innovative cementitious waste matrices have been evaluated and practiced, to immobilize evaporator concentrates. The conventional cementitious waste form relies on the use of OPC and one or more additives; typical additives include alkali and alkaline compounds, waste minerals, and clay minerals [21,23,27,36,45-55]. Table 2 summarizes the additives widely used for evaporator concentrates immobilization and their effects on the hydration process and the stabilization of the radio-contaminants [23].

Table 2. Potential additives used in designing an evaporator concentrate waste form.

\begin{tabular}{|c|c|c|c|}
\hline Category & Compound & Effect on Hydration & Effect on The Stabilization \\
\hline \multirow{3}{*}{$\begin{array}{l}\text { Alkali and alkaline } \\
\text { compounds }\end{array}$} & $\begin{array}{c}\mathrm{LiOH} \\
\mathrm{NaOH} \\
\mathrm{Na}_{2} \mathrm{SiO}_{3}\end{array}$ & $\begin{array}{l}\text { Accelerators to enhance the super-saturation of } \\
\text { the liquid phase during early hydration stage }\end{array}$ & - \\
\hline & $\mathrm{Ca}(\mathrm{OH})_{2}$ & Calcium sources and pH buffer & Stabilize amphoteric elements \\
\hline & $\mathrm{CaCl}_{2}$ & $\begin{array}{c}\text { Accelerator with several acceleration } \\
\text { mechanisms }\end{array}$ & - \\
\hline \multirow[t]{2}{*}{ Waste } & BFS * & \multirow[t]{2}{*}{ Pozzolanic materials } & $\begin{array}{l}\text { Reducing agent to enhance } \\
\text { metal precipitation } \\
\text { Bind alkali and } \\
\text { alkaline metals }\end{array}$ \\
\hline & Fly ash & & $\begin{array}{l}\text { Enhance the contaminant } \\
\text { sorption and ion-exchange }\end{array}$ \\
\hline \multirow[t]{2}{*}{ Clay mineral } & $\begin{array}{l}\text { Benotnite } \\
\text { Zeolite } \\
\text { Vermiculite } \\
\text { Diatomite }\end{array}$ & - & $\begin{array}{l}\text { Enhance the contaminant } \\
\text { sorption and ion-exchange } \\
\text { leading to reduced leaching }\end{array}$ \\
\hline & Siliceousmineral & Reducing $\mathrm{C} / \mathrm{S}$ ratio in $\mathrm{CSH}$ & - \\
\hline
\end{tabular}

* BFS = blast furnace slag.

Blends of OPC and non-gypsum cements were investigated for their potential use to solidify-simulated evaporator concentrates [40,56,57]. In a comparative study on the effect of irradiation on a specific binder matrix designed to host evaporator concentrates marked as "NP", which was composed of 50\%OPC and 50\% non-gypsum cements, and 
OPC and NP loaded with simulated evaporator concentrates (NP-C) [56], it was found that the presence of the dissolved salts e.g., nitrates, affects the performance of the latter. The compressive strengths of the samples were enhanced after irradiation, yet surface cracks were detected in NP and NP-C and were attributed to radiolysis drying [57]. Finally, the effect of wet-dry cycles on the durability of NP and 50\% non-gypsum cement with $50 \%$ metakaolin (NM), with and without $5 \%$ zeolite additives in the presence of pure fine silica and calcium sulfo-aluminate cements (CSAC) containing simulated concentrates, was investigated [40]. All the non-gypsum cement matrices showed enhanced solidification performance in terms of compressive strength and flexural strength after exposure to three wet-dry cycles. Despite CSAC showing superior compressive strength and water absorption, its exposure to the cycles led to its distortion [40].

Calcium aluminate cements (CAC), calcium sulfo-aluminate cements (CSAC), magnesium phosphate cements (MPC), alkali-activated cements (AAC), and their blends with OPC were studied to immobilize borate solutions. On the short term, these materials were found to counteract the retarding effects of boron as follows [58-71]:

- CSAC loaded with borate have higher early strength compared to OPC. This result is highly dependent on the gypsum content in the CSAC and/or the sodium content in the mix design $[58,59]$.

- Optimized AAC based on the fly ash and slag reduced the diffusion of boron in the fly ash-based matrices 100 times less than that in OPC.

- $\quad \mathrm{AAC}$ based on using $\mathrm{NaOH}$ activator and slag cement was found to counteract the retarding effect of boron if the activator is properly optimized. The use of $7 \% \mathrm{NaOH}$ in AAC yielded a compressive strength $>49.7 \mathrm{MPa}$ at $9-10 \%$ sodium borate loading [64].

- Geopolymers were investigated to immobilize borate wastes, where AAC based on metakaolin and silica fume activated with $\mathrm{KOH}$ was found efficient in immobilizing 9-14\% borate wastes with a 7-day compressive strength in the range $19-40 \mathrm{MPa}$.

- Geopolymer, known as DuraLith, has been investigated as alternative for conventional cement-based matrix to immobilize the secondary wastes from Hanford waste treatment plant in USA. The secondary wastes include evaporator concentrates and melter scrub solutions. DuraLith is AAC based on mixture of ground BFS and metakaolin with sand used as a filler material. It demonstrates compressive strength above $27 \mathrm{MPa}$ and American National Standards Institute/American Nuclear Society (ANSI/ANS) 16.1 leachability indexes for Tc as high as 9 [69-71].

- $\quad$ CSAC supplemented with $\mathrm{Ca}(\mathrm{OH})_{2}$, zeolite, accelerator, and Dura fiber was found to stabilize boron and have a compressive strength $13.9 \mathrm{MPa}$ and alkali and alkaline elements leaching rates in the range $10^{-5}-10^{-7} \mathrm{~cm} / \mathrm{d}$.

- The use of OPC-CAC and OPC-CSAC was found to be effective in stabilizing the boron in the $\mathrm{Al}_{2} \mathrm{O}_{3}-\mathrm{Fe}_{2} \mathrm{O}_{3}$-mono sulfate (AFm) and tri-sulfate (AFt) phases [65].

\subsection{Immobilization of Spent Ion Exchangers}

Ion exchangers/sorbents are widely used to remove/separate various radionuclides; it is applied for effluents of low salt content, compared to evaporators. In particular, ion exchangers are used in nuclear reactors to control system chemistry, minimize corrosion or degradation of system components, remove radioactive contaminants, and clean and decontaminate aqueous streams. Exchangers are widely used to treat the primary coolant, wet storage waters, steam generator blow down, boric acid, and condensate in boiling water reactors (BWR). This technique has efficient performance in removing and separating a wide range of elements. In addition, there are large choices of exchangers/sorbents available at the commercial scale, and its operation is known to be of low cost and easy. Yet, the operation is sensitive to the presence of organic contaminants, high salt content, colloidal/pseudo colloidal radionuclides and the extent of nonionic or non-exchangeable species, and requires regeneration to allow the reuse of the exchangers/sorbents $[23,30,72,73]$. There are several classifications for exchangers that are used to facilitate their life cycle management. Examples of these classifications and the types of materials used as ion exchangers and 
their applications in the nuclear industry are illustrated in Table 3 [23,72,74]. Another useful classification for the ion exchangers is based on the type and strength of the function group, which includes strong acidic, weak acidic, strong basic, and weak basic. At the end of their operational life, the exchangers are treated before immobilization or directly immobilized in suitable immobilization media [23,30,72].

Table 3. Examples of the classification of ion-exchangers [23,72,74].

\begin{tabular}{|c|c|c|c|c|}
\hline \multirow{2}{*}{\multicolumn{2}{|c|}{ Classification }} & \multirow{2}{*}{ Examples } & \multicolumn{2}{|c|}{ Application in Nuclear Industry } \\
\hline & & & Exchanger & Target Stream \\
\hline \multirow{4}{*}{ 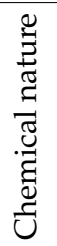 } & Inorganic & Zeolite & Clinoptilolite & SIXEP, Sellafield (remove Cs, Sr) \\
\hline & Organic & Phenol formaldehyde & Lewatit DN KR & Pond water (remove Cs) \\
\hline & & Mg-Fehydrotalcite loaded with & & \\
\hline & Hybrid & $\begin{array}{c}\text { Cyanex } 272 \\
\text { Poly-acrylamide-based } \\
\text { Ce(IV) phosphate }\end{array}$ & & - \\
\hline \multirow{4}{*}{ 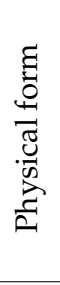 } & \multirow{2}{*}{ Bead } & Phenol formaldehyde & Lewatit DN KR & \multirow{2}{*}{$\begin{array}{c}\text { Pond water } \\
\text { AGR/Sizewell B pond water } \\
\text { (remove borate) }\end{array}$} \\
\hline & & Divinylbenzene & IRN 77 & \\
\hline & \multirow[t]{2}{*}{ Hydrogel } & $\begin{array}{c}\text { Potassium copper-hexacyanoferrate } \\
\text { embedded 3D-interconnected } \\
\text { porous hydrogel }\end{array}$ & & (1) \\
\hline & & Modified silica hydrogel $\mathrm{C}_{16} \mathrm{H}_{35} \mathrm{O}_{3} \mathrm{P}$ & & - \\
\hline \multirow{4}{*}{ 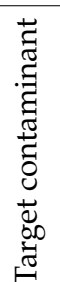 } & \multirow{3}{*}{ Cation } & \multirow{2}{*}{ Zeolite } & AW500 (synthetic) & $\begin{array}{l}\text { Pond water in Magnox Sites } \\
\text { (remove Cs) }\end{array}$ \\
\hline & & & Clinoptilolite (natural) & SIXEP, Sellafield, (remove Cs, Sr) \\
\hline & & Divinylbenzene & $\begin{array}{l}\text { IRN } 77 / 77 \mathrm{~L} \\
\text { Lewatit S100 }\end{array}$ & AGR/Sizewell B pond water \\
\hline & Anion & Divinylbenzene & $\begin{array}{c}\text { IRN } 78 / 78 \mathrm{~L} \\
\text { Lewatit MP } 62\end{array}$ & (treatment). \\
\hline
\end{tabular}

\subsubsection{General Characteristics of Spent Exchangers and Their Problematic Nature}

Spent ion exchangers as operational wastes are most often classified as LILW; the major contaminants in these exchangers are fission products, e.g., Cs, $\mathrm{Sr}$, corrosion products, borates, nitrates, and alkali components. As mentioned above, the presence of some of these contaminants can interfere with the hydration reactions. Alkali and alkaline contaminants have high solubility in the high $\mathrm{pH}$ environment. In addition, the stability of the spent exchanger can affect the performance of the produced waste form. In general, inorganic exchangers are known for their better thermal and radiation stabilities compared with the organic exchangers, and the chemical stability of both types is dependent on the solution $\mathrm{pH}$ [75]. Despite the immobilization of the exchangers in the cements generally proceed via encapsulation, limited reactions occur in the transition zone between the encapsulated exchangers and the hydrated cement. These reactions occur on the microstructure scale, but depending on their extents, they can affect the characteristics of the waste form widely. To avoid these effects, as well as potential mechanical destruction of the matrix resulting from the swelling of ion exchangers, the waste loading into the cement is limited to a small value $[23,30]$. In this respect, the following characteristics are important to be evaluated during the design of a cementitious waste form for spent ion exchangers/sorbents [23,30,72,75-82]:

1. Buffering effects of spent inorganic exchanger, which is dependent on the degree of depletion of the exchanger/sorbent. Unloaded exchangers can buffer the $\mathrm{pH}$ to fixed value over a wide range of solution $\mathrm{pH}$, this behavior is depending on the composition of the exchanger, e.g., magnetic zeolite composite can buffer the $\mathrm{pH}$ in the range 3-9 to $\mathrm{pH}=4$, and hydrotalcite-ferrocyanide composite buffers the solution in the same $\mathrm{pH}$ range to approximately neutral values $[79,80]$. If acidic buffer effect 
is noted for the spent exchanger, there will be a need to condition the stream before direct immobilization.

2. $\mathrm{pH}$ of the spent organic resin slurry, which is also dependent on the degree of the depletion of the resins, where unloaded cation and anion organic resins buffer the solution to acidic and basic media, respectively. Fully depleted resin slurry has neutral $\mathrm{pH}$. Reported study on actual spent resins slurry indicated that the solution $\mathrm{pH}$ is nearly 5 which is acceptable for direct immobilization without prior conditioning [77].

3. Water content in the exchangers, as the water content in dump resin is typically in the range of $30 \%$ and in saturated slurry is nearly $40 \%$. There is a need to optimize the water used in the mix-design to avoid the generation of large volume of bleeding water.

4. Stability of the spent ion exchangers in high $\mathrm{pH}$ environment; for inorganic exchanger, phosphates and oxyhydrates of non-ferrous metals based inorganic exchangers and zeolites are respectively stable at basic $\mathrm{pH}$ with minimum stability at $\mathrm{pH}=3$. Transition metal ferro-cyanides exchangers are unstable at $\mathrm{pH}=10$, yet the use of modified exchangers can enhance the sorption capacity and the stability in alkaline media [79].

5. Ability of the inorganic exchanger to react with cement; inorganic exchangers have a potential to interfere in the hydration reaction of the cementitious matrix. The extent of this interference is highly dependent on the reactivity of the spent exchanger and its particle size. In particular:

- Zeolite and alumina were reported to interfere in the early age hydration reaction, leading to enhanced formation of aluminosilicate phases, i.e., C3AH6, AFT, AFM.

- Cation exchanger can remove calcium and aluminum ions during the early age of hydration, leading to slow formation of C-S-H of low calcium to silica ration.

- Some inorganic exchangers were reported to have a pozzolanic activity, which is more influential during the late hydration stages.

6. Ability of the spent organic exchanger to react with cement; the ability of the exchanged contaminant to interfere with the hydration reaction is well known for organic exchangers, where:

- Resins used to treat borate streams are suspected to retard hydration as a result of boron release from the exchangers.

- Resins containing salts of short chain water soluble organic acids, e.g., acetic, formic, picolinic acids, can interfere with the hydration reactions. Examples of these resins are Purolite A200 and A400.

- Production of bleeding water should be investigated during the immobilization of anion exchange resins.

- Gel type resins, e.g., Dowex 50w-x8 ( $\mathrm{H}^{+}$form) and Dowex $11\left(\mathrm{NO}_{3}{ }^{-}\right.$form), have lower rigidity than beads and can lead to larger structural changes [81].

- Resins swelling can lead to varying effects on the solidification performance in terms of compressive strength. This behavior is more prominent in cationic exchangers.

The swelling behavior of the spent organic exchangers and the composition of the transition zone were investigated [83-86]. In a simple cementitious system, Amberlite IR120H ( $\mathrm{Na}^{+}$form) in Alite, a transient zone of small dimension was reported to occur just after setting, due to the decrease in the osmotic pressure of the external solution. Gaps were detected around the beads that separate them from the hydration products; the thickness of the gaps was reported to be dependent on the relative humidity of the SEM chamber [86]. The main internal pressure in the spent organic resin cementitious matrices is supposed to be attributed to the osmotic swelling of the resin, where cracking was proposed to occur when the generated tensile stresses exceed the maximum tensile strength of the waste forms [83]. A detailed investigation on the swelling behavior of the ion exchange resins in Alite was conducted to understand the chemical and mechanical behavior of a cementitious waste matrix containing C-S-H and portlandite only [84,85]. The studies used Amberlite IR-120 ( $\mathrm{Ca}^{+2}$ form) with a mean diameter of $0.5 \mathrm{~mm}$ and effective capacity of $5.03 \mathrm{mEq} / \mathrm{g}$ of 
dry resin. Figure 6 illustrates the SEM micrograph with elemental mapping for the studied conditions [84]. The system did not show any cracks, which employs that the stresses during solidification did not affect the matrix and the portlandite precipitated around the bead (Figure 6A). Samples immersed in $\mathrm{NaCl}$ at $1 \mathrm{~mol} / \mathrm{L}$ for three weeks did not show a massive portlandite precipitate, nor mechanical degradation (Figure 6B). This implies that the internal pressure due to the ion exchange processes is not sufficient to form cracks in the composite. Samples immersed in $\mathrm{KOH}$ showed shrinkage in the bead associated with the formation of a portlandite shell around the bead, without significant effect on the mechanical integrity (Figure 6C). Figure 6D shows the immersed sample in $\mathrm{NaOH}$ solution, and obvious cracks and bead swelling are noted and attributed to the combination of the bead swelling and portlandite precipitation. The effects of re-immersion in other alkali solutions, namely $\mathrm{KOH}, \mathrm{NaCl}$, and $\mathrm{NaOH}$, are illustrated in Figure $6 \mathrm{E}-\mathrm{G}$, respectively. For these samples, enhanced precipitation of portlandite was noted and cracks appeared for samples (F) and (G), which entail that the composition of the interstitial pore water plays a critical role in determining the mechanical integrity of the sample, where excess formation of portlandite around the bead leads to a sensible increase in the internal pressure.

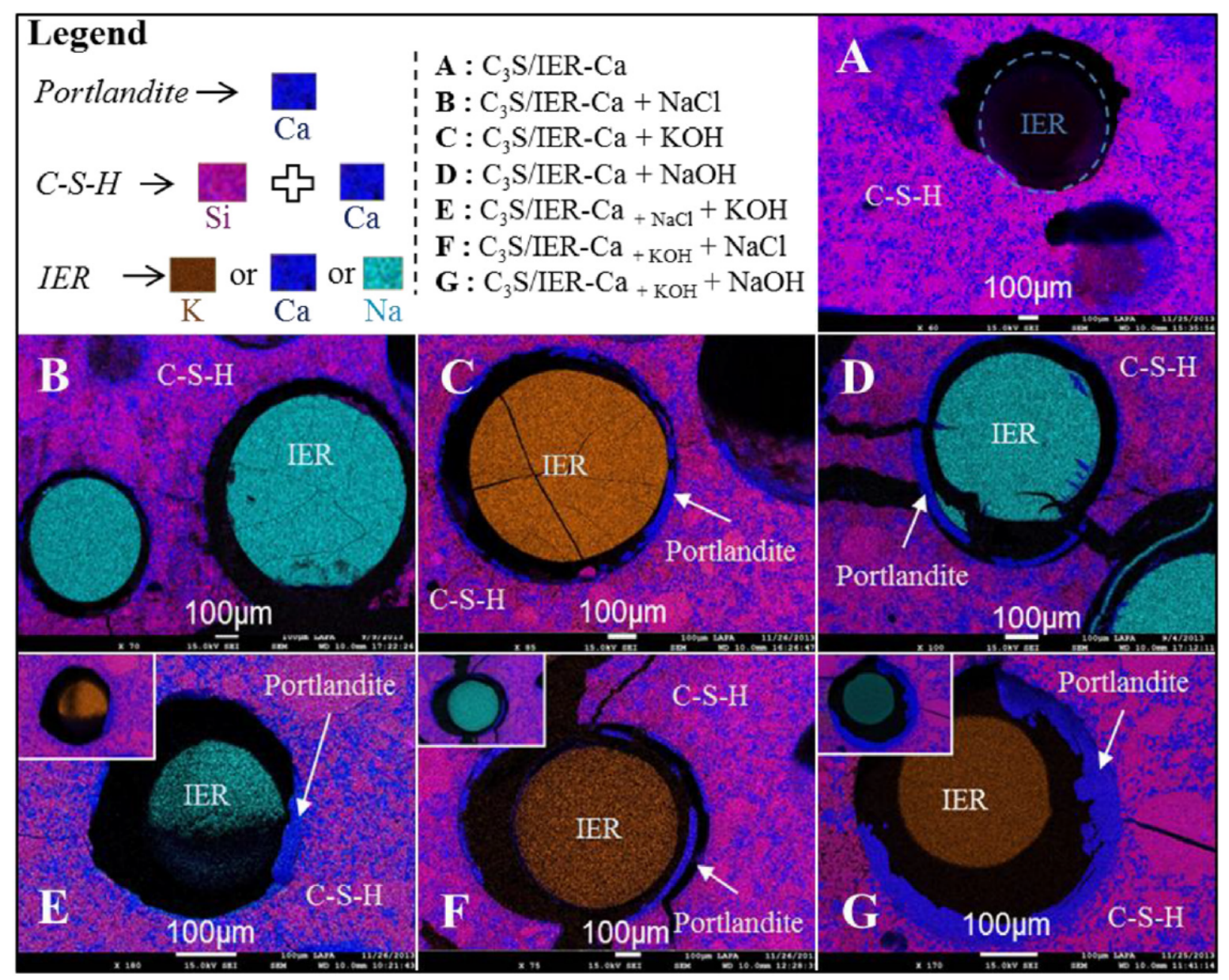

Figure 6. Elemental mapping of hydrated Alite/AmberLite IR-120 (Ca form) matrix immersed in different solutions (copyrighted from M. Neji, B. Bary, P. Le Bescop, N. Burlion, Swelling behavior of ion exchange resins incorporated in tri-calcium silicate cement matrix: I. Chemical analysis, J. Nucl. Mater. 467 (2015) 544-556).

\subsubsection{Potential Cementitious Immobilization Matrices for Spent Ion Exchangers}

Direct immobilization of spent exchangers, both organic and inorganic, in cementitiousbased materials has been practiced in different countries for more than six decades [73,87]. This practice is based either on mixing evaporator concentrates, precipitation sludge, and 
the spent exchangers using in drum mix technology or immobilizing the spent exchanger only in the cementitious matrix [23]. Examples of these applications are at Beloyarsk, Kola, Smolensk NPPs in the Russian Federation. Various conventional cementitious matrices were tested, including OPC, OPC with additives, and mixture of BFS/OPC and $\mathrm{OPC} /$ polymer. Below are some findings from these tests for the direct immobilization of this problematic operational waste $[21,23,30,52,73-78,81,82,87-98]$ :

- OPC matrices host efficiently $10 \%$ spent exchangers without any additives. As the waste loading increases, the compressive strength of the produced waste form is reduced within the first 28 days. This behavior is attributed to the reduction of the OPC content. For inorganic exchangers, in addition to the previously mentioned reason, the formation of low strength hydration phases and reduction of the $\mathrm{Ca} / \mathrm{Si}$ ratio could be responsible for this reduction. If the inorganic exchanger has a pozzolanic effect, changes in this behavior could be noted depending on the reactivity of the exchanger.

- OPC-additive matrices: additives are used increase the waste loading up to 20 and $35 \%$ for beads and gel type resins, respectively. These matrices showed improved leaching resistance and enhanced workability, depending on the nature of the additive and exchangers. In particular, the following findings are drawn:

1. OPC/natural pozzolanic materials: the addition of $1-2 \%$ natural zeolite was found to enhance the solidification of hybrid exchanger, e.g., transition metal oxide-PAN, in OPC matrix and increase the waste loading to $30 \%$ wet exchangers. Condensed silica fume/cement (II/V) was found to counteract the release of sulfate and sulfonic acid from irradiated strong acidic exchangers.

2. OPC/clay, e.g., vermiculite, bentonite, red clay, sand, optimum matrices, have enhanced stabilization performance towards $C$, where these clays provide active sites to capture Cs into the matrices.

- BFS/OPC matrices enable low hydration heat reactions, denser immobilization matrix, and better stabilization of alkali contaminants. An optimum formulation based on the type of the exchanger and the contaminants could be used to increase the waste loading safely:

1. The use of BFS/OPC with additives was also investigated to host polystyrene organic resin. The use of micro silica in that system led to achieving a waste loading $36 \%$ with acceptable $\mathrm{Cs}$ and Co leaching behavior.

2. BFS/OPC matrix was found to enhance the stability of the phenol formaldehyde resins in the immobilization matrix by mean of the pozzolanic effect.

3. OPC/polymer: this type of matrices issued to densify the structure, subsequently the solidification and stabilization performance are enhanced.

On another hand, novel cements were investigated for their application in the immobilization of spent exchangers. Zeolites (an inorganic exchanger) immobilization in CSA was found to be affected by the reaction of this exchanger with CSA between 28-90 days, leading to higher $\mathrm{Cs}$ leaching rates. This result was attributed to the distortion of the crystalline structure of zeolite and reduced C-S-H formation [74]. A ratio of 1:1 mixed bed styrene-based resins was successfully immobilized in CSA with a $20 \%$ zeolite additive at $42 \%$ loading percentage [99]. Geopolymers were extensively studied and applied to address the problems associated with the immobilization of spent exchangers. The Slovak Republic and Czech Republic have licensed this application and used it on an industrial scale $[26,27,100,101]$. At Dukovany NPP in Slovakia, 195 tones of spent resins and 4.5 tones of sludge were immobilized using a SIAL-geopolymer. The compressive strength of waste forms was in the range 12-35 MPa, where organic resins or mixtures of sludge and resins were encapsulated. The highest waste loading for the resin was $20 \%$ (on dry basis) with stainless steel drum surface dose rates in the range 130-600 $\mu \mathrm{Gy} / \mathrm{h}$, and the D value (leachability index) for ${ }^{137}$ Cs was $>9$ on cut samples from the drums. Researchs in this area were directed to investigate simple and complex immobilization matrices; the first was composed of a single precursor and alkali reactant, and the latter was composed of two 
or three precursors, an alkaline solution, additive, and/or admixture [101-108]. Table 4 summarizes the waste loading and solidification performance for the studied matrices. The investigations of the solidification and radiological stability indicated the presence of a transition zone around the cationic borate resin, immobilized in geopolymer loaded and radiolysis degradation for the resins [101,108].

Table 4. Summary of spent exchanger immobilization in different geopolymer matrices.

\begin{tabular}{|c|c|c|c|c|}
\hline \multicolumn{3}{|c|}{ AAC-MATRIX Components, wt.\% } & \multirow{2}{*}{ Exchanger Loading, \% } & \multirow{2}{*}{$\begin{array}{l}\text { Solidification at } \\
28 \text { Days, MPa }\end{array}$} \\
\hline Precursor & Alkali Reactant & Additive/Admixture & & \\
\hline GGBFS $^{\text {a }}$ & $\mathrm{Na}_{2} \mathrm{SiO}_{3} \cdot 9 \mathrm{H}_{2} \mathrm{O}+\mathrm{NaOH}$ & & $\begin{array}{l}\text { Cationic borate resin } \\
35 \%(\mathrm{pH} 8.5-10.5)\end{array}$ & $4.7-7.3$ \\
\hline Fly ash $(56 \%)$ & $\mathrm{Na}_{2} \mathrm{SiO}_{3} 20 \% \mathrm{NaOH} 8 \%$ & Super-plasticizer $6 \%$ & $10 \%$ & 6.1 \\
\hline $\mathrm{MK}^{\mathrm{b}}(29.4 \%)$ & Water glass 23.5 & $\mathrm{H}_{2} \mathrm{O} 17.6$ & Zeolite-29.4 & 37.6 \\
\hline MK & Alkaline silicate solution & - & Resin 10 & 48 \\
\hline $\begin{array}{c}\text { GGBFS }(32.7-40.8 \%) \\
\text { OPC }(8.4-9.9 \%)\end{array}$ & $\mathrm{Na}_{2} \mathrm{SiO}_{3} \cdot 5 \mathrm{H}_{2} \mathrm{O}-5.6-6.7 \%$ & $\begin{array}{l}\text { Bentonite } 2.8-8.2 \% \text {, } \\
\mathrm{Ca}(\mathrm{OH})_{2}-4.9-5.6 \%\end{array}$ & $43.2-45.1$ & $6.4-12.6$ (at 14 day) \\
\hline $\begin{array}{c}\text { GGBFS }(34.2-40.2 \%) \\
\text { OPC }(8.8 \%)\end{array}$ & $\mathrm{Na}_{2} \mathrm{CO}_{3}-1.6-3 \%$ & $\begin{array}{c}\text { Bentonite } 2.5-5.2 \% \\
\mathrm{Ca}(\mathrm{OH})_{2} 4-4.9 \% \\
\mathrm{H}_{2} \mathrm{O} 5.9-11.1\end{array}$ & $41.9-45$ & 8.4-13.2 (at 11 day) \\
\hline $\begin{array}{c}\text { MK+ Feldspar } \\
\text { MK+ Feldspar + BFS }\end{array}$ & Alkaline silicate solution & & Resin $8-12 \%$ & $\begin{array}{l}42 \\
48\end{array}$ \\
\hline $\begin{array}{c}\text { MK }(41.9-33.5 \%) \\
\text { BFS }(4.2-8.4 \%)\end{array}$ & Sodium silicate/NaOH 58.1\% & & $12 \%$ & 13.63 \\
\hline
\end{tabular}

${ }^{\mathrm{a}}$ GGBFS $=$ ground granulated blast furnace slag. ${ }^{\mathrm{b}}$ Metakaolin $=$ MK.

\subsection{Immobilization of Organic Liquid Operational Wastes}

Organic materials are used during the operation of nuclear power plants; they are classified based on their physical nature as solid and liquid materials. At the end of their operational life, most of these materials become radiologically contaminated and should be treated as radioactive wastes. Examples of organic solid wastes include contaminated clothing, plastic sheets and bags, rubber gloves, mats, shoe covers, and paper wipes. Examples of organic liquid wastes include contaminated lubricating oils and hydraulic fluids from reactor operation, scintillation liquids from radio-analytical laboratories, and miscellaneous solvents/diluents generated from decontamination activities and nuclear fuel processing [21,33,109-111]. These wastes could be treated then immobilized or directly immobilized, and there are several available techniques to treat these wastes, including destructive technologies, either chemical or thermal, and non-destructive technologies, i.e., physical $[23,112,113]$. Organic solid wastes could be physically treated using compaction and then directed to immobilization in cement, where they are encapsulated without potential interference in the hydration reactions.

\subsubsection{General Characteristics of Organic Liquid Wastes and Their Problematic Nature}

In general, the characteristics of organic liquid wastes are dependent on the chemical composition of the organic agents, the nature of the applications, and the extent of hydrolysis and radiolysis of the organic components. The common radiological characteristics of these wastes are as follow [109-114]:

- $\quad$ Oils are generated in small volume compared to aqueous wastes and include lubricating oils, hydraulic fluids, and vacuum pump oils. Oils from reactor operations are classified as LLW, where they are contaminated with relatively small amounts of beta and gamma emitting radionuclides, e.g., ${ }^{137} \mathrm{Cs},{ }^{134} \mathrm{Cs},{ }^{58} \mathrm{Co},{ }^{60} \mathrm{Co}$, and ${ }^{65} \mathrm{Zn}$. Some lubricating oils in hot cells are contaminated with alpha emitting radionuclides. In PHWR, spent vacuum pump oils are classified as ILW. 
- Scintillation liquids are used in radiochemical analysis of low energy alpha and beta emitters. They include both non-aqueous and non-polar solvents. The radioactivity content in these wastes is about $350 \mathrm{MBq} / \mathrm{m}^{3}$,

- Miscellaneous solvents are used in the decontamination activities, including organic acids and solvent, e.g., toluene, carbon tetrachloride, acetone, alcohols, and trichloroethane. Their activity contents are $<200 \mathrm{MBq} / \mathrm{m}^{3}$. In addition, solvents used in the solvent extraction processes, widely used in nuclear fuel reprocessing, belong to this class. The latter is generated in respectively high volumes.

Depending on the chemical structure of these wastes, they can be volatile, flammable, and toxic. Safe management of these wastes includes either treatment or direct immobilization [109-117]. Direct immobilization of organic liquid wastes in a cement matrix is challenged by $[23,74,118,119]$ :

- The interference of the organic components with the hydration reactions of the cementitious matrix leads to retardation in the setting of the cementitious paste and creation of porous matrix, where the organic liquid components cover the anhydrous cement grains and prevent them from reaction with water. This behavior is more notable for polar solvents.

- The retention of the organic components is mainly dependent on physical entrapment, i.e., encapsulated in cavities, not the chemical bonds with cement, which will make them vulnerable to leaching.

- Organic liquid wastes are susceptible to radiolysis, thermal and microbial degradation, which is associated with gas releases that can initiate cracking.

These challenges limit the full-scale practice of organic liquid wastes immobilization into conventional cementitious matrices to a $10-12 \%$ loading.

\subsubsection{Cementitious Immobilization Matrices for Organic Liquid Wastes}

Several additives and admixtures were proposed to increase the organic liquid waste loading into conventional cementitious waste matrices. These include clays, silica- or calcium-based additives, and emulsifiers. Three techniques were practiced for producing acceptable cementitious waste forms, which are pre-emulsification, direct mixing, and pre-impregnation $[21,23,113,119,120]$ :

1. Pre-emulsification is a two-step technique, in which a stable emulsion is prepared by mixing the organic wastes with water in the presence or absence of emulsifier. In the second step, the emulsion is added to the mixed blend of OPC and the additive. This method was applied in USA and reported to be sensitive to changes in the waste composition. Pre-emulsification was also used in Cernavoda nuclear power plant in Romania to prepare cementitious waste forms for the immobilization of spent scintillation liquid contaminated with tritium $[119,120]$. In that practice, the oil and water are emulsified using high shear mixer then added to the cement.

2. Direct mixing is a single step technique, in which all the waste matrix components, e.g., OPC, additive, waste, water, and emulsifier if needed, are mixed until achieving a homogenous paste. The waste loading is limited in this case.

3. Pre-impregnation is also a two-step technique, in which the organic liquid is impregnated onto suitable sorbent, then the impregnated sorbent is mixed with the OPC and water to produce homogenous waste form paste. The increase in the waste form volume, due to the use of sorbent, is counterweighed with the low generated volumes of these wastes.

Figure 7 illustrates different mix designs for typical applications of pre-emulsification and pre-impregnation techniques in the immobilization of spent oil in conventional cementitious matrices. Data presented reveal that the pre-impregnation technique is sensitive to the type of used additive, where variable (15-56\%) organic liquid waste loadings were achieved. 


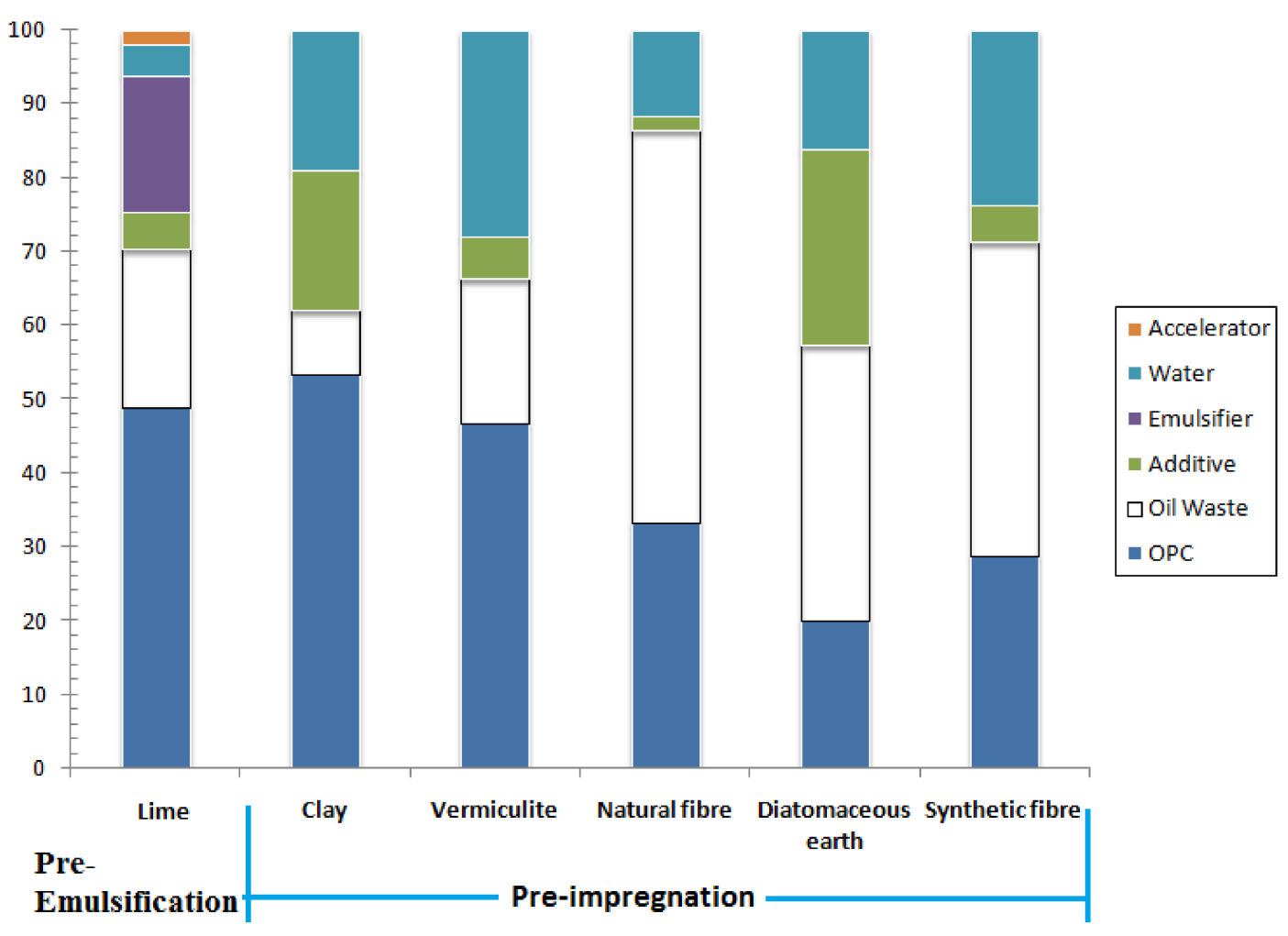

Figure 7. Typical composition of a conventional cementitious waste immobilization matrix for spent oil.

Research efforts are continuing to find suitable design mixes for improving the immobilization of organic liquid wastes, and among these efforts are [118,120-123]:

- Pre-emulsification technique was investigated to immobilize alpha contaminated lubricating oil in conventional cementitious matrix. Stable emulsion was prepared by mixing the oil and $\mathrm{NaOH}$ solution. Then, silica fumes were added to form solubilized silicate. Finally, the cement was added. This waste form was reported to enable the accommodation of $20 \%$ oil in cement and has acceptable alpha, beta, and gamma stabilization performances.

- $\quad$ Thermal expanded graphite (TEG) and bentonite clay were tested to immobilize TBP and spent oil contaminated with Cs and Sr. Pre-impregnation technique was followed, where TEG was impregnated with the organic liquid wastes then mixed with OPC, bentonite, and water. The effect of water immersion, freeze-thaw cycles, irradiation up to 250 KGy on the solidification performance, and Cs and Sr stabilizations were investigated. $25 \%$ TBP and $20 \%$ spent oil were successfully immobilized in the matrix at $\mathrm{w} / \mathrm{c}$ ration 0.3 . This matrix was recommended to have 42 days curing prior to transportation.

- Natural clay was used as additive to immobilize spent scintillation liquid following direct mixing technique. The liquid waste was dispersed into OPC-3\% clay composite at $0.3 \mathrm{w} / \mathrm{c}$ ration then mixed to achieve homogenous paste. The matrix showed acceptable resistance to freeze-thaw and good stabilization performance under flooding conditions.

A study was performed to compare the performance of conventional and innovative cementitious forms in immobilizing organic liquid wastes [124]. In that study, lime, zeolite, and emulsifier were proposed to immobilize simulated TBP from the PUREX process in the conventional OPC matrix and innovative CSA matrix. The results indicated that at 28 days, the OPC matrix has a higher compressive strength and is more durable under freezing and irradiation conditions. Under flooding conditions, the compressive strength 
of CSA increased over that of OPC. The study concluded that CSA has a better stabilization performance than OPC.

A recent review summarized the progress of the incorporation of organic liquid in geopolymers, classifying the incorporation process into three classes similar to those used in conventional cementitious matrices [125]. Examples on the application of these classes in recent research to immobilize different organic liquid wastes include [126-128]:

- Pre-emulsification: the immobilization of simulated TBP from PUREX in phosphateacid base geopolymer was investigated. The matrix, loaded with $18 \%$ waste, was reported to have compressive strength equals 59.19 MPa. Exposure to flooding and freeze conditions led to a reduction in the strength by 10 and $25 \%$, respectively [126].

- Pre-impregnation: simulated radwaste oils immobilization in metakaolin-based geopolymers was studied. Bentonite and commercial polymer N910 were tested for oil pre-impregnation, then the matrix was prepared using Metakaolin and mixture of $\mathrm{Na}_{2} \mathrm{SiO}_{3}$ and $\mathrm{NaOH}$. The analysis showed that the pre-impregnation of the oil using bentonite with $2 \%$ commercial polymer meets the Brazilian requirements on the stabilization performance [127].

- Pre-impregnation: the immobilization of simulated Lix84 loaded with copper in geopolymer was investigated. The metakaolin was impregnated with the extractant. Then, the binder was activated by adding the alkaline solution. $8 \%$ waste loading was achieved with acceptable stabilization performance [128].

\section{Optimizing the Mix Design}

The optimization of the mix design for any waste form is guided by available quality requirements on nuclear cement, paste operability characteristics, and the waste acceptance criteria (WAC) for the storage or disposal facility, as indicated in Section 2. Based on the national legislation, quality requirements on nuclear cements can be applied to the cement and additives used in producing the cementitious waste form. In this case, quality requirements on the raw materials and the produced waste form should be followed. Compliance with these requirements is usually ensured by conducting a standardized index experiment, e.g., grading and density $[129,130]$. The operability characteristics are determined in view of available cementation technologies in the facility/country. There are two classes of mixing technologies that are widely used in nuclear waste cementation, namely in drum mixing and grout batch mixing $[21,23]$. The features of each and available technologies are addressed elsewhere $[21,23]$. The mix design should be optimized so the paste possesses the following characteristics:

- Adequate flow-ability to allow the cementitious paste to flow freely from the mixer either in-drum or batch.

- Sufficient liquid content to minimize bleeding water.

- Setting time is longer than the process cycle, e.g., mixing, pouring, and mixer dripping, if any.

WAC are derived based on the safety case of a facility and include certain performance measures, e.g., limits on release rates, compressive strength, permeability, surface dose, and others [23]. These performances are usually evaluated based on the expected (natural) evolution scenario of the facility combined with hydraulic failure [131]. Within this context, accelerated aging or accidental procedures are applied to the waste form, then its performance is investigated [130]. These procedures can include repeated freeze-thaw cycles, wet-dry cycles, flooding, and dropping. Then, the performance measures are evaluated, e.g., the stabilization performance is evaluated using a suitable leaching test, and the solidification performance is evaluated by measuring the compressive strength, etc. During the optimization process, there are several options that could be considered during the design of the testing program. These include selection of the testing procedure, the factors that affect the waste form performance, and the optimization technique. Figure 8a-c illustrates the classification of the leaching tests, the factors considered during the design of these tests, and the optimization options. 


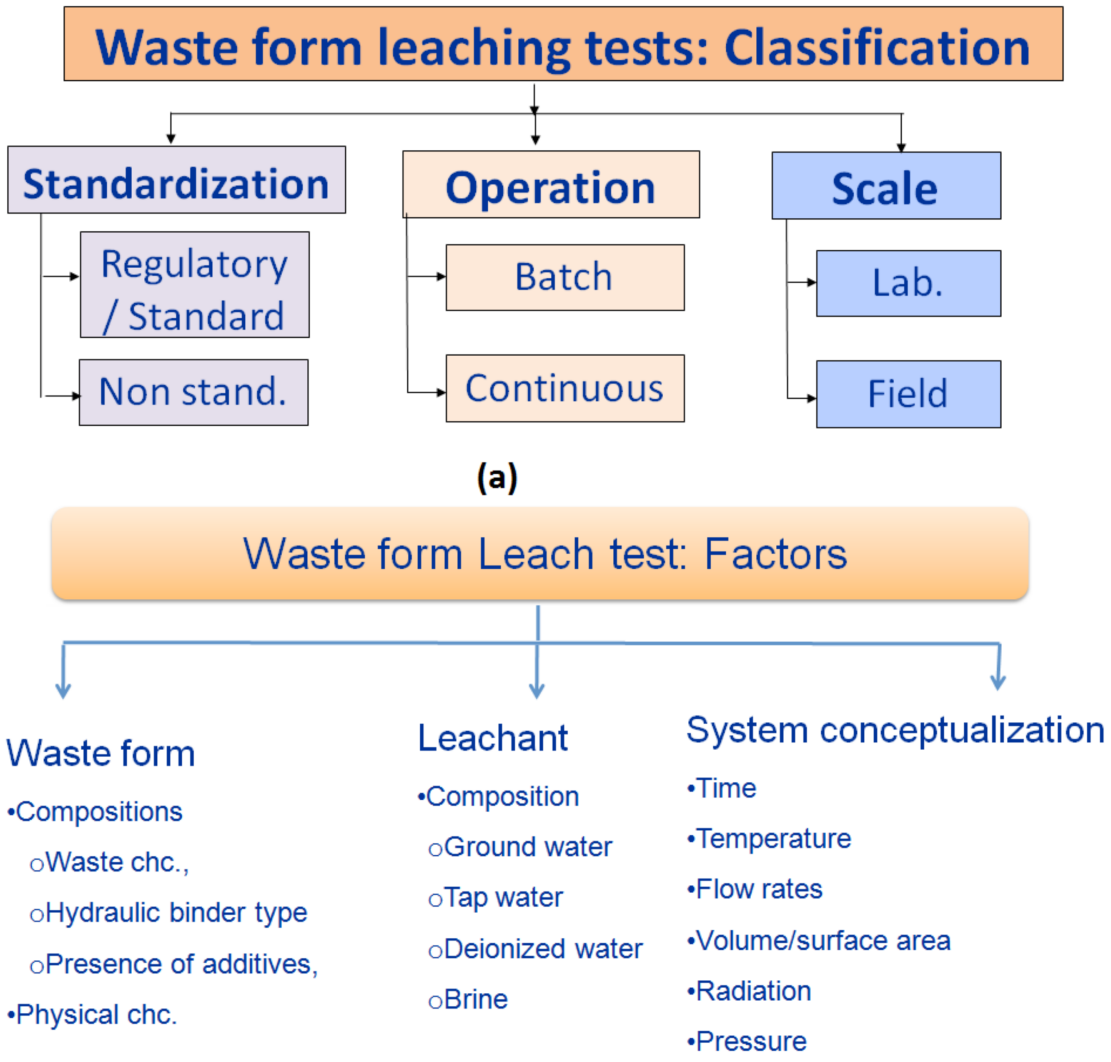

(b)

Waste form Leach test: Optimization

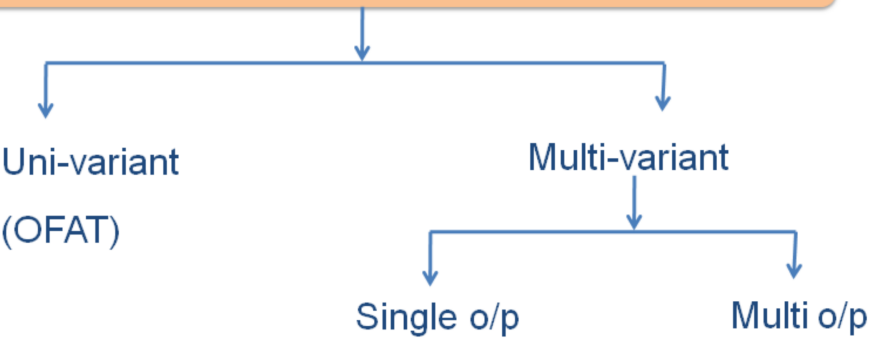

(c)

Figure 8. Waste form leaching test (a) classifications, (b) factors that affect the performance, and (c) optimization technique.

\subsection{Leaching Test Procedure}

Leaching procedures are conducted by contacting the waste form and a leachant (typically either deionized or natural water). Then, samples of the leachant are drawn and analyzed to determine the release of elements of interest, e.g., contaminants or structural elements. The features, advantages, and limitations of each test class, illustrated in Figure 8 a, are listed in Table $5[23,26,130,132]$. Leaching tests are not only used to design the waste form composition but are used to support the quality control program and provide inputs for the disposal assessment as well. Leaching can be accelerated by using granular particles, de-mineralized water, and applying high flow rates, temperature, or pressure. The selection of the leaching test procedure should be guided by the aims of conducting the tests, stage of the design phase, and WAC requirements. 
Table 5. Features, advantages, and limitations of different leaching test classes.

\begin{tabular}{|c|c|c|c|}
\hline Class & Feature & Advantage & Limitation \\
\hline \multicolumn{4}{|c|}{ Standardization } \\
\hline Standardized & $\begin{array}{l}\text { Well-defined and controlled conditions, } \\
\text { e.g., ASTM C } 1308 \text { and ANSI/ANS-16.1 }\end{array}$ & $\begin{array}{l}\text { Allows inter-comparison of } \\
\text { the results of different waste } \\
\text { forms from different places }\end{array}$ & $\begin{array}{l}\text { Usually provide conservative } \\
\text { estimates of } \\
\text { radio-contaminants release }\end{array}$ \\
\hline Non-standardized & $\begin{array}{l}\text { Flexible condition, e.g., large scale } \\
\text { field experiments }\end{array}$ & $\begin{array}{c}\text { Allow mimicking actual } \\
\text { concern about specified } \\
\text { waste form }\end{array}$ & $\begin{array}{l}\text { Results cannot be } \\
\text { generalized easily }\end{array}$ \\
\hline \multicolumn{4}{|c|}{ Mode of Operation } \\
\hline Batch & $\begin{array}{l}\text { Static and semi-dynamic standardized } \\
\text { and non-standardized leaching tests } \\
\text { are used } \\
\text { The semi-dynamic tests include total } \\
\text { renewal of the leachate at } \\
\text { pre-determined periods, e.g., ANS16.1 } \\
\text { Static leach tests do not include renewal } \\
\text { orcirculation of the leachant, e.g., MCC }\end{array}$ & $\begin{array}{l}\text { Mimics slow flow conditions } \\
\text { Simplicity of operation } \\
\text { Small scale } \\
\text { Robust and simple models are } \\
\text { available to analyze the } \\
\text { experimental data }\end{array}$ & $\begin{array}{l}\text { Relatively slow compared } \\
\text { with continuous models }\end{array}$ \\
\hline Continuous & $\begin{array}{l}\text { Flow through measure the release } \\
\text { under conservative conditions, e.g., } \\
\text { ASTM extraction column }\end{array}$ & $\begin{array}{c}\text { Accelerated tests } \\
\text { Simulate conservative } \\
\text { conditions compared to that } \\
\text { in Batch experiment }\end{array}$ & $\begin{array}{l}\text { The modeling aspects are } \\
\text { more complicated than those } \\
\text { used for analyzing the batch } \\
\text { experimental data }\end{array}$ \\
\hline \multicolumn{4}{|c|}{ Scale of application } \\
\hline $\mathrm{Lab}$ & $\begin{array}{c}\text { Both standardized and } \\
\text { non-standardized tests are used }\end{array}$ & $\begin{array}{l}\text { Simpler and cheaper } \\
\text { compared to field tests } \\
\text { Complete control of the } \\
\text { experiment conditions }\end{array}$ & $\begin{array}{l}\text { Need further investigations to } \\
\text { up scale the results }\end{array}$ \\
\hline Field & Non-standardized tests & $\begin{array}{l}\text { Simulate the performance } \\
\text { under true site-specific } \\
\text { conditions }\end{array}$ & $\begin{array}{l}\text { Hard to achieve } \\
\text { complete control }\end{array}$ \\
\hline
\end{tabular}

\subsection{Selection of the Waste Simulants}

There are three options applied to investigating the potential use of a specified mix design and simulating the interactions of the radioactive wastes with the cementitious matrix. The selection of the most appropriate option is dependent on the problem formulation, and the options can be as follows:

1. Use stable solutions containing only potential radio-contaminants, e.g., Cs, Sr, I, etc.

2. Use simulated waste stream, e.g., simulated stable salt solutions of evaporator concentrate, precipitate, or loaded resin with stable isotopes.

3. Use simulated waste stream loaded with radioactive isotope.

The use of a stable isotope stimulant is justified by the similar chemical performance of the radioactive and stable isotopes, so the stabilization and solidification results will not be affected. Moreover, using stable simulants eliminates the radiological doses to workers. A recent review summarized the used solutions in studying the stable solutions for assessing the performance of nuclear waste forms and indicated that for, $\mathrm{Cs}, \mathrm{Sr}$, and $\mathrm{Co}$, the most commonly used solutions for cementitious waste form testing are chlorides and nitrates [133]. In depth analysis of the contaminant speciation during the early hydration stage is important to evaluate the binding mechanisms of these contaminants [91,92]. The speciation results of $\mathrm{Cs}, \mathrm{Sr}$, and $\mathrm{Co}$ chloride solutions indicated that the solutions contain $100 \% \mathrm{Cs}^{+}$, a mixture of $\left(\mathrm{Sr}^{+2}\right.$, and $\left.\mathrm{SrCl}^{+}\right)$, and a mixture of $\left(\mathrm{Co}^{+2}, \mathrm{CoOH}^{+}, \mathrm{Co}(\mathrm{OH})_{2} \mathrm{aq}\right.$, $\left.\mathrm{Co}(\mathrm{OH})_{3}{ }^{-}\right)[91,92,134] . \mathrm{Cl}^{-}$is the only available species for $\mathrm{Cs}$ and Co solutions, and a mixture of $\mathrm{Cl}^{-}$and $\mathrm{SrCl}^{+}$species exists in $\mathrm{Sr}$ solutions. The precise proportion of available species for stabilization/binding is $\mathrm{pH}$ dependent. Upon mixing these solutions 
with OPC-based materials, the unhydrated cement grains start to dissolute, leading to an increase in the solution $\mathrm{pH}$. A reported study indicated that $\mathrm{Cs}^{+}$is the only detected species in the mixing solution independent on the presence of the OPC, additive, or another contaminant [91]. Using simulated evaporator concentrates and precipitates will complicate the speciation study for divalent and higher valency contaminants, depending on the composition of the solutions. An analysis of the interfacial water composition during the initial leaching of borosilicate glass indicated that a small portion of Sr will react with borate [131].

\subsection{Selection of Additive Type}

As indicated in Section 2, additives are used to improve the operability, solidification, and stabilization performances of conventional and innovative cementitious waste forms via several mechanisms. In a recent study, the general effects of the additives on the solidification performance, based on their shape, were concluded as follows [135]:

- Fine particle fillers, e.g., slag, fly ash, and silica fume can improve the pore structure and increase the compressive strength.

- $\quad$ Fiber additives are used to improve the tensile strength.

Recently, nano-materials have been tested as additives for cementitious waste forms [136,137]. The practical implementation still requires a lot of investigation $[6,135,138]$. During the selection of the additive, a prior precise evaluation of the problematic nature of the waste stream and required WAC should be conducted.

\subsection{Solid and Liquid Contents Proportion}

As the proportion of the mix design for both conventional and innovative cementitious waste forms highly affect the form performance, there is a need to identify the optimum proportion of the mix design, taking into consideration the following [21,23,30,56,93,139]:

- For liquid wastes, e.g., evaporator concentrates, saline wastes, increasing the waste loading will be associated with the formation of porous materials and subsequently reduce the compressive strength and increase the permeability.

- For matrices that contain additives of considerable water sorbtivity, the determination of the water content is crucial, where using low water content will reduce the degree of hydration and subsequently reduced the solidification and stabilization performance and affect the flow-ability of the paste.

- For wet solid wastes, e.g., spent ion exchangers, the water content should be carefully adjusted to minimize the bleeding water.

- For matrices that contain additives, the reactivity of the additives should be evaluated, and the amount of the additives should be optimized to ensure the formation of sufficient hydration phases to achieve the required stabilization performance.

\subsection{Selection of Optimization Techniques}

Optimization techniques are divided into uni-variant, i.e., one factor at a time (OFAT), and multivariate techniques (MVT) (Figure 8c). The first is conducted by fixing all the studied factors at a fixed value and changing only one factor at a time, whereas in the second, all the factors are changed simultaneously. Table 6 lists the features, advantages, and limitations of both techniques [80]. Due to the complexity of the design process, where there are large numbers of factors and performance measures that should be considered, the optimization process usually proceeds via three steps toward the final durable waste form, as follow:

1. Identifying the mix design: in this step, the precise waste loading and liquid and solid proportions are identified. Both optimization techniques can be used in this step.

2. Test the robustness of the mix design: in this step, the ability of the optimum mix design to accommodate wastes with fluctuated chemical composition is tested. In this 
case, multi-variant techniques are preferred, as they provide an easy way to identify the main interacting factors and enable setting controls on them.

3. Validation for industrial scale application: in this step, the performance of industrial scale waste forms istested and usually OFAT is adopted.

Table 6. Comparison between the optimization techniques.

\begin{tabular}{cccc}
\hline Technique & Feature & Advantage & Limitation \\
\hline OFAT & $\begin{array}{c}\text { Evaluate isolated effects of the studied } \\
\text { factors on a single performance measure } \\
\text { Empirical, mechanistic, and black box } \\
\text { models are used to analyze the data }\end{array}$ & $\begin{array}{c}\text { Allow the determination of } \\
\text { mechanisms, interpolate and } \\
\text { extrapolate the process } \\
\text { performance }\end{array}$ & $\begin{array}{c}\text { Does not allow the determination } \\
\text { of the effect of interaction } \\
\text { between the factors that affect } \\
\text { the performance }\end{array}$ \\
MVT & $\begin{array}{c}\text { Evaluate the effects of the studied factors' } \\
\text { variability and their interactions on } \\
\text { single and multi-performance measures }\end{array}$ & $\begin{array}{c}\text { Identify the main } \\
\text { influencing factors } \\
\text { Provide insights into the } \\
\text { system reliability }\end{array}$ & $\begin{array}{c}\text { Does not allow the determination } \\
\text { of the mechanism }\end{array}$ \\
\hline
\end{tabular}

\section{Conclusions}

Cementitious materials are widely applied as immobilization media to host radioactive wastes, including problematic waste streams for which routine technologies need modifications to account for their specific parameters. Sustainability considerations during the design of cementitious matrices are important, and here we have analyzed the characteristics of problematic operational waste streams resulting from nuclear energy utilization, such as evaporator concentrates, spent ion exchangers, and organic liquid wastes. The components that interfere with the hydration reaction of cements are the key characteristics required for assessing the factors that affect the production of cementitious waste forms. A guide for optimizing the mix design of cementitious waste forms was developed that considers the features, advantages, and disadvantages of different leaching test categories, options to simulate the wastes, additives, water and solid components, and the adopted optimization techniques. Over the past decades, cementitious matrices proved their ability to produce sustainable waste forms for containing problematic operational wastes. A lot of efforts are still needed to optimize the mix design of these forms, and research in these areas can include the investigation of the use of wastes and nano-materials as additives to reduce the amount of cement used and improve the operational and long-term performance of these matrices. Investigations of sustainable and green solutions to increase the waste loading and maintain the long-term durability of the produced waste form are of great importance.

Author Contributions: Conceptualization, R.O.A.R.; resources, M.I.O. and R.O.A.R.; writingoriginal draft preparation, R.O.A.R. and M.I.O.; writing—review and editing, R.O.A.R. and M.I.O. All authors have read and agreed to the published version of the manuscript.

Funding: This research received no external funding.

Institutional Review Board Statement: Not applicable.

Informed Consent Statement: Not applicable.

Data Availability Statement: Not applicable.

Acknowledgments: The authors acknowledge the critical comments by anonymous reviewers, which helped to improve the review.

Conflicts of Interest: The authors declare no conflict of interest. 


\section{References}

1. Abdel Rahman, R.O.; Ojovan, M.I. Introduction to the nuclear industry sustainability. In Sustainability of Life Cycle Management for Nuclear Cementation-Based Technologies; Abdel Rahman, R.O., Ojovan, M.I., Eds.; Elsevier-Woodhead Publishing: Chichester, UK, 2021; pp. 3-47. [CrossRef]

2. Kroger, W. Measuring the sustainability of energy systems. NEA News 2001, 19, 21-24.

3. OECD. Nuclear Energy in a Sustainable Development Perspective; Nuclear Energy Agency: Paris, France, 2000.

4. IAEA. Nuclear Power and Sustainable Development; International Atomic Energy Agency: Vienna, Austria, 2016.

5. Pearce, J.M. Limitations of Nuclear Power as a Sustainable Energy Source. Sustainability 2012, 4, 1173-1187. [CrossRef]

6. Abdel Rahman, R.O.; Metwally, S.S.; El-Kamash, A.M. Improving the Performance of Engineering Barriers in Radioactive Waste Disposal Facilities: Role of Nano-Materials. In Handbook of Nanomaterials and Nanocomposites for Energy and Environmental Applications; Kharissova, O., Martínez, L., Kharisov, B., Eds.; Springer: Cham, Switzerland, 2021; pp. 1183-1200. [CrossRef]

7. IAEA. IAEA Safety Glossary, Terminology Used in Nuclear Safety and Radiation Protection, 2018th ed.; International Atomic Energy Agency: Vienna, Austria, 2019.

8. Conner, J.R.; Hoeffner, S.L. The History of Stabilization/Solidification Technology. Crit. Rev. Environ. Sci. Technol. 1998, 28, 325-396. [CrossRef]

9. Heacock, H.W. Alternative Nuclear Waste Solidification Processes; University of Arizona: Tucson, AZ, USA, 1975 ; pp. 177-206.

10. Mullarkey, T.B.; Jentz, T.L.; Connelly, J.M.; Kane, J.P. A Survey and Evaluation of Handling and Disposing of Solid Low-Level Nuclear Fuel Cycle Wastes; Atomic Industrial Forum Inc.: Washington, DC, USA, 1976.

11. NRC. Solidification of High-Level Radioactive Wastes; U.S. National Regulatory Center National Academy of Engineering: Washington, DC, USA, 1979.

12. Schneider, K.J. Solidification of Radioactive Wastes. Chem. Eng. Prog. 1970, 66, 35.

13. Conner, J.R.; Hoeffner, S.L. A Critical Review of Stabilization/Solidification Technology. Crit. Rev. Environ. Sci. Technol. 1988, 28, 397-462. [CrossRef]

14. Abdel Rahman, R.O.; Guskov, A.; Kozak, M.W.; Hung, Y.T. Recent Evaluation of Early Radioactive Disposal Practice. In Handbook of Environmental Engineering; Wang, L., Wang, M.H., Hung, Y.T., Shammas, N., Eds.; Natural Resources and Control Processes; Springer: Cham, Switzerland, 2016; pp. 371-400.

15. Cote, P.; Gilliam, M. Environmental Aspects of Stabilization and Solidification of Hazardous and Radioactive Wastes; STP 1033; ASTM: Philadelphia, PA, USA, 1989.

16. Gilliam, T.M.; Wiles, C.C. Stabilization and Solidification of Hazardous, Radioactive, and Mixed Wastes; STP 1123; ASTM: Philadelphia, PA, USA, 1992; Volume 2.

17. Laguna, W. Radioactive Waste Disposal by Hydraulic Fracturing. In Purdue Univ. Eng. Bull. Ext. Ser.; 1970, 137. Available online: https:/ / www.osti.gov/biblio/5980790 (accessed on 27 October 2021).

18. Conner, J.R. Ultimate Disposal of Liquid Wastes by Chemical Fixation. In Proceedings of the 29th Annual Purdue Industrial Waste Conference, West Lafayette, IN, USA, 7-9 May 1974.

19. Batchelor, B. Overview of waste stabilization with cement. Waste Manag. 2006, 26, 689-698. [CrossRef] [PubMed]

20. IAEA. Management of Problematic Waste and Material Generated during the Decommissioning of Nuclear Facilities; TRS 441; International Atomic Energy Agency: Vienna, Austria, 2006.

21. Varlakov, A.; Zherebtsov, A. Innovative and conventional materials and designs of nuclear cementitious systems in radioactive waste management. In Sustainability of Life Cycle Management for Nuclear Cementation-Based Technologies; Abdel Rahman, R.O., Ojovan, M.I., Eds.; Elsevier-Woodhead Publishing: Chichester, UK, 2021; pp. 297-338. [CrossRef]

22. IAEA. Improved Cement Solidification of Low and Intermediate Level Radioactive Waste; TRS. 350; International Atomic Energy Agency: Vienna, Austria, 1993.

23. Abdel Rahman, R.O.; Rakhimov, R.Z.; Rakhimova, N.R.; Ojovan, M.I. Cementitious Materials for Nuclear Waste Immobilization; Wiley: New York, NY, USA, 2014; ISBN 9781118512005. [CrossRef]

24. Heath, T.; Schofield, J.; Shelton, A. Understanding cementitious backfill interactions with groundwater components. J. Appl. Geochem. 2020, 113, 104495. [CrossRef]

25. Stefan, L.; Varet, T.; Lamouroux, C. Cementation of Nuclear Wastes: From Past to Future in a Sustainable Approach. In Proceedings of the WM2018 Conference, Phoenix, AZ, USA, 18-22 March 2018.

26. Drace, Z.; Mele, I.; Ojovan, M.I.; Abdel Rahman, R.O. An overview of research activities on cementitious materials for radioactive waste management. Mater. Res. Soc. Symp. Proc. 2012, 1475, 253-264. [CrossRef]

27. IAEA. Behaviour of Cementitious Materials in Long-Term Storage and Disposal of Radioactive Waste; IAEA-TECDOC-1701; International Atomic Energy Agency: Vienna, Austria, 2013.

28. International Atomic Energy Agency (IAEA). Requirements and Methods for Low and Intermediate Level Waste Package Acceptability; IAEA TECDOC-864; International Atomic Energy Agency: Vienna, Austria, 1996.

29. IAEA. Characterization of Radioactive Waste Forms and Packages; TRS-383; International Atomic Energy Agency: Vienna, Austria, 1997.

30. Abdel Rahman, R.O.; Zaki, A.A. Comparative analysis of nuclear waste solidification performance models: Spent ion exchangercement based wasteforms. Process Saf. Environ. Prot. 2020, 136, 115-125. [CrossRef] 
31. Dmitriev, S.A.; Lifanov, F.A.; Savkin, A.E.; Lashchenov, C.M. Handling of the Bottom Residues of a Nuclear Power Plant. At. Energy 2000, 89, 884-889. [CrossRef]

32. Kononenko, O.A.; Milyutin, V.V.; Makarenkov, V.I.; Kozlitin, E.A. Immobilization of NPP Evaporator Bottom High Salt-Bearing Liquid Radioactive Waste into Struvite-Based Phosphate Matrices. J. Hazard. Mater. 2021, 416, 125902. [CrossRef]

33. Pátzay, G.; Weiser, L.; Feil, F.; Patek, G. Analysis and Selective Treatment of Radioactive Waste Waters and Sludges. In Waste Water-Evaluation and Management; Einschlag, F.S.G., Ed.; InTech: Rijeka, Croatia, 2011; ISBN 9789533072333. Available online: https:/ / www.intechopen.com/chapters/14576 (accessed on 27 October 2021).

34. Matsuzuru, H.; Moriyama, N.; Wadachi, Y.; Ito, A. Leaching behavior of Cesium-137 in cement-waste composites. Health Phys. 1977, 32, 529-534. [CrossRef]

35. Abdel Rahman, R.O.; Ojovan, M.I. Recent Trends in the Evaluation of Cementitious Material in Radioactive Waste Disposal. In Handbook of Environmental Engineering; Wang, L., Wang, M.H., Hung, Y.T., Shammas, N., Eds.; Natural Resources and Control Processes; Springer: Cham, Switherland, 2016; Volume 17, pp. 401-448. [CrossRef]

36. Anton, S.; Milan, Z. Borate compound content reduction in liquid radioactive waste from nuclear power plants with VVER reactor. In Proceedings of the International Conference Nuclear Energy in Central Europe 2000, Golf Hotel, Bled, Slovenia, 11-14 September 2000.

37. Kononenko, O.A.; Gelis, V.M.; Milyutin, V.V. Incorporation of bottoms from nuclear power plants into a matrix based on portland cement and silicic additives. At. Energy 2011, 109, 278-284. [CrossRef]

38. Li, B.; Ling, X.; Liu, X.; Li, Q.; Chen, W. Hydration of Portland cement in solutions containing a high concentration of borate ions: Effects ofLiOH. Cem. Concr. Compos. 2019, 102, 94-104. [CrossRef]

39. Zhao, Q.; Tu, J.; Han, W.; Wang, X.; Chen, Y. Hydration Properties of Portland Cement Paste with Boron Gangue. Adv. Mater. Sci. Eng. 2020, 2020, 7194654. [CrossRef]

40. Zatloukalova, J.; Zatloukal, J.; Hraníček, J.; Kolář, K.; Konvalinka, P. Study on the properties of cement composites for immobilization of evaporator concentrates. Prog. Nucl. Energy 2021, 140, 103919. [CrossRef]

41. Wang, Y.; Huang, B.; Mao, Z.; Deng, M.; Cao, H. Effect of a Boric Acid Corrosive Environment on the Microstructure and Properties of Concrete. Materials 2020, 13, 5036. [CrossRef] [PubMed]

42. Csetenyi, L.J.; Glasser, F.P. Borate retardation of cement set and phase relations in the system $\mathrm{Na}_{2} \mathrm{O}-\mathrm{CaO}-\mathrm{B}_{2} \mathrm{O}_{3}-\mathrm{H}_{2} \mathrm{O} \cdot A d v \cdot C e m$. Res. 1995, 7, 13-19. [CrossRef]

43. Abdel Rahman, R.O.; Ojovan, M.I. Sustainability of cementitious structures, systems, and components (SSC's): Long-term environmental stressors. In Sustainability of Life Cycle Management for Nuclear Cementation-Based Technologies; Abdel Rahman, R.O., Ojovan, M.I., Eds.; Elsevier-Woodhead Publishing: Chichester, UK, 2021; pp. 181-232. [CrossRef]

44. Varlakov, A.; Zherebtsov, A.; Ojovan, M.I.; Petrov, V. Long-term irradiation effectsin cementitious systems. In Sustainability of Life Cycle Management for Nuclear Cementation-Based Technologies; Abdel Rahman, R.O., Ojovan, M.I., Eds.; Elsevier-Woodhead Publishing: Chichester, UK, 2021; pp. 161-180. [CrossRef]

45. Goni, S.; Guerrero, A.; Lorenzo, M.P. Efficiency of fly ash belite cement and zeolite matreices for immobilizing cesium. J. Hazard. Mater. 2006, B 137, 1608-1617. [CrossRef]

46. Sun, Q.; Li, J.; Wang, J. Effect of borate concentration on solidification of radioactive wastes by different cements. Nucl. Eng. Des. 2011, 241, 4341-4345. [CrossRef]

47. Guerrero, A.; Goñi, S. Efficiency of a blast furnace slag cement for immobilizing simulated borate radioactive liquid waste. J. Waste Manag. 2002, 22, 831-836. [CrossRef]

48. Sinha, P.K.; Shanmugamani, A.G.; Renganathan, K.; Muthiah, R. Fixation of radioactive chemical sludge in a matrix containing cement and additives. Ann. Nucl. Energy 2009, 36, 620-625. [CrossRef]

49. Reddy, D.A.; Khandelwal, S.K.; Muthiah, R.; Shanmugamani, A.G.; Paul, B.; Rao, S.V.S.; Sinha, P.K. Conditioning of sludge produced through chemical treatment of radioactive liquid waste; operating experiences. Ann. Nucl. Energy 2010, 37, 934-941. [CrossRef]

50. Osmanlioglu, A.E. Immobilization of radioactive borate liquid waste using natural diatomite. Desalin. Water Treat. 2016, 57, 15146-15153. [CrossRef]

51. Polyakov, A.S.; Masanov, O.L.; Zakharova, K.P. Cementing of radioactive salt concentrates. At. Energy 1994, 77, 468-470. [CrossRef]

52. El-Kamash, A.M.; El-Naggar, M.R.; El-Dessouky, M.I. Immobilization of cesium and strontium radionuclides in zeolite-cement blends. J. Hazard. Mater. 2006, 136, 310-316. [CrossRef]

53. Varlakov, A.P. Development of a unified technological process for cementing liquid radioactive wastes. At. Energy 2010, 109, 16-21. [CrossRef]

54. Poluektova, G.B.; Smirnov, Y.V.; Sokolova, I.D. Processing and Disposal of Radioactive Waste from Nuclear Industry Companies in Foreign Countries. Central Research and Development Institute for Management, Economics and Information of the Ministry of Nuclear Industry of the Russian Federation, Moscow; CNIIatominform: Moscow, Russia, 1990.

55. Plecas, I.; Dimovic, S. Immobilization of Cs and Co in concert matrix. Ann. Nucl. Energy 2003, 30, 1899-1903. [CrossRef]

56. Zatloukalová, J.; Marty, V.D.; Zatloukal, J.; Kolár, K.; Guillot, W.; Konvalinka, P. Investigation of radiolysis in cement pastes immobilizing simulatedevaporatorconcrentrates. Ann. Nucl. Energy 2021, 151, 107901. [CrossRef] 
57. Zatloukalova, J.; Marty, V.D.; Zatloukal, J.; Kolar, K.; Hlavac, Z.; Konvalinka, P. Mechanical properties of irradiated cement pastes for immobilization of evaporator concentrates. Prog. Nucl. Energy 2020, 127, 103437. [CrossRef]

58. Champenois, J.B.; Coumes, C.C.D.; Poulesquen, A.; Le Bescop, B.; Damidot, D. Conditioning highly concentrated borate solutions with calcium sulfoaluminate cement. In Cement-Based Materials for Nuclear Waste Storage; Bart, F., Coumes, C.C.D., Frizon, F., Lorente, S., Eds.; Springer: New York, NY, USA, 2013; pp. 203-214.

59. Champenois, J.B.; Dhoury, M.; Coumes, C.C.D.; Mercier, C.; Revel, B.; Le Bescop, P.; Damidot, D. Influence of sodium borate on the early age hydration of calcium sulfoaluminate cement. Cem. Concr. Res. 2015, 70, 83-93. [CrossRef]

60. Qina, S.; Wang, J. Cementation of radioactive borate liquid waste produced in pressurized water reactors. Nucl. Eng. Des. 2010, 240, 3660-3664.

61. Hall, D.A. The effect of retarders on the microstructure and mechanical properties of magnesiaephosphate cement mortar. Cem. Concr. Res. 2001, 31, 455-465. [CrossRef]

62. Yang, J. Effect of borax on hydration and hardening properties of magnesium and potassium phosphate cement pastes. J. Wuhan. Univ. Techn. Mater. Sc. Ed. 2010, 25, 613-618. [CrossRef]

63. Palomo, A.; De la Fuente, J.I. Alkali-activated cementitious materials: Alternative matrices for the immobilisation of hazardous wastes, part I. Stabilisation of boron. Cem. Concr. Res. 2003, 33, 281-288. [CrossRef]

64. Rakhimova, N.R.; Rakhimov, R.Z.; Morozov, V.P.; Potapova, L.I.; Osin, Y.N. Mechanism of solidification of simulated borate liquid wastes with sodium silicate activated slag cements. J. Clean. Prod. 2017, 149, 60-69. [CrossRef]

65. Champenois, J.B.; Mesbah, A.; Coumes, C.C.D.; Renaudin, G.; Leroux, F.; Mercier, C.; Revel, B.; Damidot, D. Crystal structures of Boro-AFm and sBoro-AFt phases. Cement Concr. Res. 2012, 42, 1362-1370. [CrossRef]

66. Coumes, C.C.D.; Courtois, S.; Peysson, S.; Ambroise, J.; Pera, J. Calcium sulfoaluminate cement blended with OPC: A promising binder to encapsulate low-level radioactive slurries of complex chemistry. Cem. Concr. Res. 2009, 39, 740-747. [CrossRef]

67. Hernandez, S.; Guerrero, A.; Goni, S. Leaching of borate waste cement matrices: Pore solution and solid phase characterization. Adv. Cem. Res. 2000, 12, 1-8. [CrossRef]

68. Kwan, B.; Lee, J.; Kang, J.; Um, W. Development of geopolymer waste form for immobilization of radioactive borate waste. J. Hazard. Mater. 2021, 419, 126402.

69. Jantzen, C.M.; Lee, W.E.; Ojovan, M.I. Radioactive waste (RAW) conditioning, immobilisation, and encapsulation processes and technologies: Overview and advances. Chapter 6. In Radioactive Waste Management and Contaminated Site Clean-Up: Processes, Technologies and International Experience; Woodhead: Cambridge, UK, 2013; pp. 171-272.

70. Pierce, E.M.; Um, W.; Cantrell, K.J.; Valenta, M.M.; Westsik, J.H.; Serne, R.J., Jr.; Parker, K.E. Secondary Waste Form Screening Test Results_Cast Stone and Alkali Alumino-Silicate Geopolymer; PNNL-19505; PNNL: Washington, WA, USA, 2011.

71. Mattigod, S.V.; Westsik, J.H. Secondary Waste Form Down-Selection Data Package—DuraLith; PNNL-20718; Pacific Northwest National Laboratory: Richland, WA, USA, 2011.

72. Abdel Rahman, R.O.; Metwally, S.S.; El-Kamash, A.M. Life Cycle of Ion Exchangers in Nuclear Industry: Application and Management of Spent Exchangers. In Handbook of Ecomaterials; Martínez, L., Kharissova, O., Kharisov, B., Eds.; Springer: Cham, Switzerland, 2019; pp. 3709-3732. [CrossRef]

73. IAEA. Applications of Ion Exchange Processes for the Treatment of Radioactive Waste and Management of Spent Ion Exchangers; TRS-408; International Atomic Energy Agency: Vienna, Austria, 2002.

74. Utton, C.; Godfrey, I.H. Review of Stability of Cemented Grouted Ion-Exchange Materials, Sludges and Flocs; National Nuclear Laboratory: Warrington, UK, 2010.

75. Ojovan, M.I.; Lee, W.E. An Introduction to Nuclear Waste Immobilisation; Elsevier: Amsterdam, The Netherlands, 2014.

76. Arnold, G.; Fuhrmann, M.; Colombo, P.; Kalb, P.; Doty, R.; Kemeny, P.; Franz, E.M.; Neilson, R.M.; Reilly, S., Jr. Solidification of Ion Exchange-Resin Wastes, Brookhaven National Laboratory; Brookhaven National Laboratory Upton: New York, NY, USA, 1982.

77. Faiz, Z.; Bouih, A.; Fakhi, S.; Laissaoui, A.; Hannache, H.; Idrissi, A. Improvement of conditions for the radioactive ion exchange resin immobilization in the cement Portland. J. Mater. Environ. Sci. 2015, 6, 289-296.

78. Laili, Z.; Yasir, M.S.; Abdul Wahab, M.; Mahmud, N.A.; Zainal Abidin, N. Evaluation of the compressive strength of cement-spent resins matrix mixed with biochar. Malays. J. Anal. Sci. 2015, 19, 565-573.

79. Gasser, M.S.; Mekhamer, H.S.; Abdel Rahman, R.O. Optimization of the utilization of Mg/Fe hydrotalcite like Compounds in the removal of Sr(II) from aqueous solution. J. Environ. Chem. Eng. 2016, 4, 4619-4630. [CrossRef]

80. Abdel Rahman, R.O.; Abdel Moamen, O.A.; Abdelmonem, N.; IsmailI, M. Optimizing the removal of strontium and cesium ions from binary solutions on magnetic nano-zeolite using response surface methodology (RSM) and artificial neural network (ANN). Environ. Res. 2019, 173, 397-410. [CrossRef] [PubMed]

81. Howard, C.G.; Jolliffe, C.B.; Lee, D.J. Immobilization of Ion-Exchange Resins in Cement, Contract No FI1W-0006-UK, Commission of the European Communities, Directorate-General Telecommunications; Information Industries and Innovation L-2920; Commision of the European Communities: Luxembourg, 1991.

82. Veazey, G.W.; Ames, R.L. Cement Waste-Form Development for Ion-Exchange Resins at the Rocky Flats Plant; LA-13226-MS; Los Alamos National Laboratory: Los Alamaos, NM, USA, 1997.

83. Matsuda, M.; Nishi, T.; Chino, K.; Kikuchi, M. Solidification of Spent Ion Exchange Resin Using New Cementitious Material, (I) Swelling Pressure of Ion Exchange Resin. J. Nucl. Sci. Technol. 1992, 29, 883-889. [CrossRef] 
84. Neji, M.; Bary, B.; Le Bescop, P.; Burlion, N. Swelling behavior of ion exchange resins incorporated in tri-calcium silicate cement matrix: I. Chemical analysis. J. Nucl. Mater. 2015, 467, 544-556. [CrossRef]

85. Neji, M.; Bary, B.; Le Bescop, P.; Burlion, N. Swelling behavior of ion exchange resins incorporated in tri-calcium silicate cement matrix: II. Mechanical analysis. J. Nucl. Mater. 2015, 467, 863-875. [CrossRef]

86. Lafond, E.; Coumes, C.C.D.; Gauffinet, S.; Chartier, D.; Le Bescop, P.; Stefan, L.; Nonat, A. Investigation of the swelling behavior of cationic exchange resins saturated with $\mathrm{Na}+$ ions in a C3S paste. Cem. Concr. Res. 2015, 69, 61-71. [CrossRef]

87. IAEA. Treatment and Conditioning of Spent Ion Exchange Resins from Research Reactors, Precipitation Sludges and Other Radioactive Concentrates; IAEA-TECDOC-689; International Atomic Energy Agency: Vienna, Austria, 1993.

88. Abdel Rahman, R.O.; Zaki, A.A. Comparative study of leaching conceptual models: Cs leaching from different ILW cement based matrices. Chem. Eng. J. 2011, 173, 722-736. [CrossRef]

89. Li, J.; Wang, J. Advances in cement solidification technology for waste radioactive ion exchange resins: A review. J. Hazard. Mater. 2006, B135, 443-448. [CrossRef]

90. Osmanlioglu, A.E. Immobilization of radioactive waste by cementation with purified kaolin clay. Waste Manag. 2015 , 2, 481-483. [CrossRef]

91. Abdel Rahman, R.O.; Zein, D.H.; Abo Shadi, H. Cesium binding and leaching from single and binary contaminant cementbentonite matrices. Chem. Eng. J. 2014, 245, 276-287. [CrossRef]

92. Abdel Rahman, R.O.; Zein, D.H.; Abo Shadi, H. Assessment of strontium immobilization in cement-bentonite matrices. Chem. Eng. J. 2013, 228, 772-780. [CrossRef]

93. Phillip, E.; Khoo, K.S.; Yusof, M.A.W.; Abdel Rahman, R.O. Assessment of POFA-cementitious material as backfill barrier in DSRS borehole disposal: ${ }^{226}$ Ra confinement. J. Environ. Manage. 2021, 28, 111703. [CrossRef]

94. Sebesta, F.; John, J.; Motl, A. Development of Composite Ion Exchangers and Their Use in Treatment of Liquid Radioactive Wastes, Waste Treatment and Technologies Involving Inorganic Sorbents; Final Report of a Co-Ordinated Research Programme 1992-1996 IAEA-TECDOC-947; IAEA: Vienna, Austria, 1997; pp. 79-105.

95. Nurokhim, L.T. Immobilization Of 137Cs on Cement-Zeolite Composites, Waste Treatment and Technologies Involving Inorganic Sorbents; Final Report of a Co-Ordinated Research Programme 1992-1996 IAEA-TECDOC-947; IAEA: Vienna, Austria, 1997; pp. 153-163.

96. Plecas, I.; Pavlovic, R.; Pavlovic, S. Leaching behaviour of $60 \mathrm{Co}$ and $137 \mathrm{Cs}$ from spent ion exchange resins in cement-bentonite clay matrix. J. Nucl. Mater. 2004, 327, 171-174. [CrossRef]

97. Osmanlioglu, A.E. Progress in cementation of reactor resins. Biol. Sci. 2007, 49, 20-26. [CrossRef]

98. Plecas, I.; Dimovic, S. Influence of natural sorbents on the immobilization ofspent ion exchange resins in cement. J. Radioanal. Nucl. Chem. 2006, 269, 181-185. [CrossRef]

99. Junfeng, L.; Gong, Z.W.; Jianlong, W. Solidification of low level-radioactive resins in ASC zeolite blends. Nucl. Eng. Des. 2005, 235, 817-821. [CrossRef]

100. IAEA. Use of Benchmarking System for Operational Waste from WWER Reactors; TECDOC-1815; IAEA: Vienna, Austria, 2017.

101. Lichvar, P.; Rozloznik, M.; Sekely, S. Behaviour of Aluminosilicate Inorganic Matrix Sial during and after Solidification of Radioactive Sludge and Radioactive Spent Resins and Their Mixtures; Amec Nuclear Slovakia. 2010. Available online: https: //www-pub.iaea.org/MTCD/Publications/PDF/TE-1701_add-CD/PDF/Slovakia.pdf (accessed on 27 October 2021).

102. Rakhimova, N.R.; Rakhimov, R.Z.; Lutskin, Y.S.; Morozov, V.P.; Osin, Y.N. Solidification of borate ion-exchange resins by alkali-activated slag cements. Rom. J. Mater. 2018, 48, 177-184.

103. Lee, W.H.; Cheng, T.W.; Ding, Y.C.; Lin, K.L.; Tsao, S.W.; Huang, C.P. Geopolymer technology for the solidification of simulated ion exchange resins with radionuclides. J. Environ. Manag. 2019, 235, 19-27. [CrossRef] [PubMed]

104. Lin, W.H.; Chen, H.Y.; Huang, C.P. Performance study of ion exchange resins solidification using metakaolin-based geopolymer binder. Prog. Nucl. Energy 2020, 129, 103508. [CrossRef]

105. Khairudin, N.W.A.; Yasir, M.S.; Majid, A.A.; Wahab, M.A. Immobilisation of spent ion exchange resin from PuspatiTRIGA reactor using ash-based geopolymer. Malays. J. Anal. Sci. 2015, 19, 472-480.

106. Kryvenko, P.; Petropavlovskyi, O.; Cao, H.; Weng, L.; Kovalchuk, O. Applicability of alkali-activated cement for immobilization of low-level radioactive waste in ion-exchange resins. East. Eur. J. Enterp. Technol. 2015, 6, 40-45. [CrossRef]

107. Xu, Z.; Jiang, Z.; Wu, D.; Peng, X.; Xu, Y.; Li, N.; Qi, Y.; Li, P. Immobilization of Strontium-Loaded Zeolite A by Metakaolin Based-Geopolymer. Ceram. Int. 2017, 43, 4434-4439. [CrossRef]

108. El-Naggar, M.R.; El-Masry, E.H.; El-Sadek, A.A. Assessment of individual andmixed alkali activated binders for solidification of a nuclear grade organic resin loaded with 134Cs, 60Co and 152+154 Eu radionuclides. J. Hazard. Mater. 2019, 375, 149-160. [CrossRef]

109. Abdel Rahman, R.O.; Kozak, M.W.; Hung, Y.-T. Radioactive pollution and control, Ch (16). In Handbook of Environment and Waste Management; Hung, Y.T., Wang, L.K., Shammas, N.K., Eds.; World Scientific Publishing Co.: Singapore, 2014 ; pp. 949-1027.

110. Abdel Rahman, R.O.; Ibrahium, H.A.; Hung, Y.-T. Liquid radioactive wastes treatment: A Review. Water 2011, 3, 551-565. [CrossRef]

111. Romanovsky, V.; Pokhitonov, Y.; Kelley, D. Prospects on Immobilization of Liquid Organic Radwastes with the Use of High Technology Polymers-14065. In Proceedings of the WM2014 Conference, Phoenix, AZ, USA, 2-6 March 2014.

112. IAEA. Design and Operation of Radioactive Waste Incineration Facilities; Safety Series No. 921; IAEA: Vienna, Austria, 1992.

113. IAEA. Treatment and Conditioning of Radioactive Organic Liquids; TECDOC 656; IAEA: Vienna, Austria, 1992. 
114. IAEA. Reference Design for a Centralized Waste Processing and Storage Facility; IAEATECDOC-776; IAEA: Vienna, Austria, 1994.

115. IAEA. Handling and Processing of Radioactive Waste from Nuclear Applications; Technical Reports Series No. 402; IAEA: Vienna, Austria, 2001.

116. IAEA. Combined Methods for Liquid Radioactive Waste Treatment; IAEA-TECDOC 1336; IAEA: Vienna, Austria, 2003.

117. IAEA. Predisposal Management of Organic Radioactive Waste; Technical Reports Series No. 427; IAEA: Vienna, Austria, 2004.

118. Manohar, S.; Sasidharan, N.S.; Wattal, P.K.; Shah, N.J.; Chander, M.; Bansal, N.K. Immobilization of Alpha Contaminated Lubricantingoul in Cement Matrix, Government of India. BARC/2000/E/036; Bhabha Atomic Energy Commission: Mumbai, India, 2000.

119. Teoreau, I.; Deneanu, N.; Dulama, M. Matrix Materials for the conditioning organic radioactive wastes. Romn J. Mater. 2010, 40, 112-121.

120. Dianu, M.; Podină, C. The safety of environment in final disposal of ultima gold scintillation liquid cocktail used for determination of the radioactive content in various samples at cernavoda nuclear power plant. Rev. Roum Chim. 2007, 52, 509-519.

121. Nikitin, A.V.; Kondakova, Y.V.; Sazonov, A.B. Combined Matrixes for Solidification of Organic Radioactive Liquid Wastes Containing Cs-137 and Sr-90. Inorg. Mater. Appl. Res. 2017, 8, 681-690. [CrossRef]

122. Eskander, S.B.; Abdel Aziz, S.M.; El-Didamony, H.; Sayed, M.I. Immobilization of low and intermediate level of organic radioactive wastes in cement matrices. J. Hazard. Mater. 2011, 190, 969-979. [CrossRef]

123. El-Didamony, H.; Bayoumi, T.A.; Sayed, M.I. Evaluation of the Properties of Cemented Liquid Scintillator Wastes under Flooding Scenario in Various Aqueous. Int. Sch. Res. Netw. 2012, 2012, 373795. [CrossRef]

124. Zhang, W.; Li, J.; Wang, J. Solidification of spent radioactive organic solvent by sulfoaluminate and Portland cements. J. Nucl. Sci. Technol. 2015, 52, 1362-1368. [CrossRef]

125. Reeb, C.; Pierlot, C.; Davy, C.; Lambertin, D. Incorporation of organic liquids into geopolymer materials-A review of processing, properties and applications. Ceram. Int. 2021, 47, 7369-7385. [CrossRef]

126. Dong, T.; Xie, S.; Wang, J.; Zhao, G.; Song, Q. Solidification and stabilization of spent TBP/OK organic liquids in a phosphate acid-based geopolymer. Sci. Technol. Nucl. Install. 2020, 2020, 8094205. [CrossRef]

127. Cuccia, V.; Freire, C.B.; Ladeira, A.C.Q. Radwaste oil immobilization in geopolymer after non-destructive treatment. Prog. Nucl. Energy 2020, 122, 103246. [CrossRef]

128. El-Naggar, M.R.; El-Sherief, E.A.; Mekhemar, H.S. Performance of geopolymers for direct immobilization of solvent extraction liquids: Metakaolin/LIX-84 formulations. J. Hazard. Mater. 2018, 360, 670-680. [CrossRef] [PubMed]

129. Al-Tabbaa, A.; Perera, A.S.R. Stabilisation/solidification treatment and remediation part IV: Testing \& performance criteria. In Proceedings of the International Conference on Stabilisation/Solidification Treatment and Remediation, Cambridge, UK, 12-13 April 2005; pp. 415-435.

130. Abdel Rahman, R.O.; Ojovan, M.I. Leaching Tests and Modelling of Cementitious Waste forms Corrosion. Innov. Corros. Mater. Sci. 2014, 4, 90-95. [CrossRef]

131. Farid, O.M.; Ojovan, M.I.; Abdel Rahman, R.O. Evolution of cations speciation during the initial leaching stage of alkaliborosilicate-glasses. MRS Adv. 2020, 5, 185-193. [CrossRef]

132. Abdel Rahman, R.O.; Ojovan, M.I. Techniques to test cementitious systems through their life cycles. In Sustainability of Life Cycle Management for Nuclear Cementation-Based Technologies; Abdel Rahman, R.O., Ojovan, M.I., Eds.; Woodhead Publishing: Chichester, UK, 2021; pp. 407-430. [CrossRef]

133. Li, J.; Xu, D.; Wang, W.; Wang, X.; Mao, Y.; Zhang, C.; Jiang, W.; Wu, C. Review on Selection and Experiment Method of Commonly Studied Simulated Radionuclides in Researches of Nuclear Waste Solidification. Sci. Technol. Nucl. Install. 2020, 2020, 3287320. [CrossRef]

134. Gasser, M.S.; El Sherif, E.; Mekhamer, H.S.; Abdel Rahman, R.O. Assessment of Cyanex 301 impregnated resin for its potential use to remove cobalt from aqueous solutions. Environ. Res. 2020, 185, 109402. [CrossRef] [PubMed]

135. Li, J.; Chen, L.; Wang, J. Solidification of radioactive wastes by cement-based materials. Prog. Nucl. Energy 2021, $141,103957$. [CrossRef]

136. Cao, B.; Fan, S.; Tan, X.; Li, M.; Hu, Y. Cementitious materials modified with hematite nanoparticles for enhanced cement hydration and uranium immobilization. Environ. Sci. Nano 2017, 4, 1670-1681. [CrossRef]

137. Fan, S.; Cao, B.; Deng, N.; Hu, Y.; Li, M. Effects of ferrihydrite nanoparticle incorporation in cementitious materials on radioactive waste immobilization. J. Hazard. Mater. 2019, 379, 120570. [CrossRef]

138. Abdel Rahman, R.O.; Ojovan, M.I. Application of nano-materials in radioactive waste management. In Environmental Science and Engineering. Industrial Processes \& Nanotechnology Ch (15); Tian, C.Z., Bhola, R.G., Govil, J.N., Eds.; Studium Press LLC: New York, NY, USA, 2017; Volume10, pp. 361-378, ISBN 101626990980.

139. Abdel Rahman, R.O.; Zaki, A.A. Assessment of the leaching characteristics of incineration ashes in cement matrix. Chem. Eng. J. 2009, 155, 698-708. [CrossRef] 